\title{
Response of the ice cap Hardangerjøkulen in southern Norway to the 20th and 21 st century climates
}

\author{
R. H. Giesen and J. Oerlemans \\ Institute for Marine and Atmospheric research Utrecht, Utrecht University, P.O. Box 80005, 3508 TA Utrecht, \\ The Netherlands
}

Received: 27 October 2009 - Published in The Cryosphere Discuss.: 13 November 2009

Revised: 4 May 2010 - Accepted: 7 May 2010 - Published: 12 May 2010

\begin{abstract}
Glaciers respond to mass balance changes by adjusting their surface elevation and area. These properties in their turn affect the local and area-averaged mass balance. To incorporate this interdependence in the response of glaciers to climate change, models should include an interactive scheme coupling mass balance and ice dynamics. In this study, a spatially distributed mass balance model, comprising surface energy balance calculations, was coupled to a vertically integrated ice-flow model based on the shallow ice approximation. The coupled model was applied to the ice cap Hardangerjøkulen in southern Norway. The available glacio-meteorological records, mass balance and glacier length change measurements were utilized for model calibration and validation. Forced with meteorological data from nearby synoptic weather stations, the coupled model realistically simulated the observed mass balance and glacier length changes during the 20th century. The mean climate for the period 1961-1990, computed from local meteorological data, was used as a basis to prescribe climate projections for the 21 st century at Hardangerjøkulen. For a linear temperature increase of $3^{\circ} \mathrm{C}$ from 1961-1990 to 2071-2100, the modelled net mass balance soon becomes negative at all altitudes and Hardangerjøkulen disappears around the year 2100. The projected changes in the other meteorological variables could at most partly compensate for the effect of the projected warming.
\end{abstract}

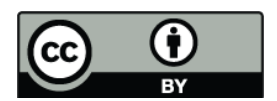

Correspondence to: R. H. Giesen (r.h.giesen@uu.nl)

\section{Introduction}

Glacier volume projections are required to assess the rate of sea level rise expected from ice wastage in a warmer future climate (e.g., IPCC, 2007; Meier et al., 2007; Bahr et al., 2009). In order to obtain reliable estimates for a particular climate scenario, observed differences in glacier response for various glacier types and climatic regions first need to be understood.

In contrast to other regions in Scandinavia and the global trend, the maritime glaciers in mainland Norway advanced in the late 20th century, following a series of wet winters around 1990 (Andreassen et al., 2005). Since the year 2000, all monitored glaciers in Norway had a net mass deficit and retreated (Kjøllmoen et al., 2008). On the maritime Norwegian glaciers, the interannual variability in the net mass balance is dominated by variations in the winter balance, while summer balance fluctuations are more important on the glaciers further inland (Andreassen et al., 2005). The high dependence on winter precipitation suggests that the future of the maritime Norwegian glaciers is not only determined by the degree of warming, but also by the accompanying change in precipitation.

Regarding the spatial distribution of glaciers in southern Norway, the large glaciers $\left(>25 \mathrm{~km}^{2}\right)$ are all situated within $150 \mathrm{~km}$ from the coast, in a maritime to transitional climate regime. All these glaciers are ice caps, with a large and flat upper part and a number of steeper outlet glaciers. Ice caps are particularly sensitive to climate change, because a small increase in the equilibrium-line altitude (ELA) can turn a large part of the accumulation area into ablation area (Nesje et al., 2008).

Published by Copernicus Publications on behalf of the European Geosciences Union. 


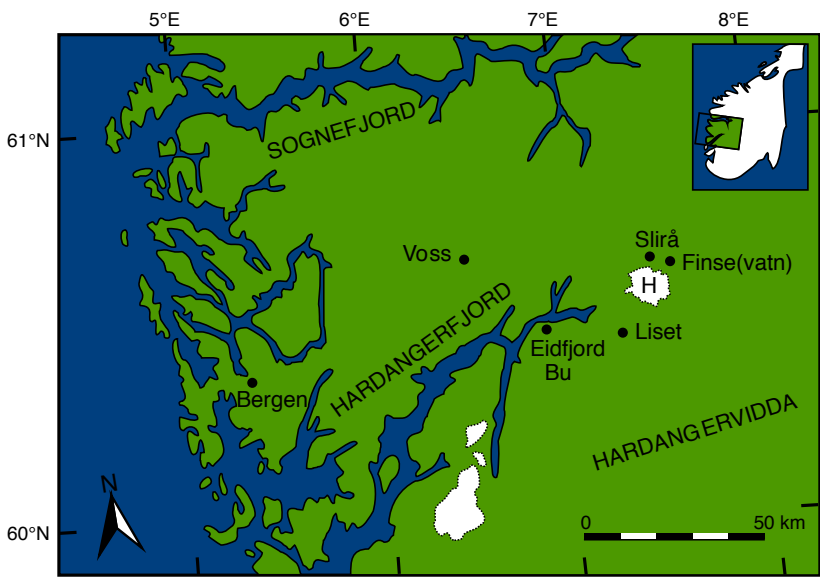

Fig. 1. Map showing the location of Hardangerjøkulen $(\mathrm{H})$ in southern Norway and the locations of the synoptic weather stations from which records are used in this study.

In this study, we determine the response of the ice cap Hardangerjøkulen in southern Norway to the observed climate in the 20th century and projected climate change for the 21 st century. Hardangerjøkulen is situated in the transitional zone between the maritime glaciers near the western coast and the more continental glaciers further inland (Andreassen et al., 2005; Giesen et al., 2009). We employ a spatially distributed surface mass balance model to account for horizontal precipitation gradients and topographic effects, especially on solar irradiance. All individual energy and mass balance fluxes are defined as functions of principal meteorological variables, which is essential to translate changes in climate to a change in surface mass balance. Simple relations, for instance between air temperature and ablation, may no longer be valid in a climate that is much warmer than the climate used to calibrate the relationship. The surface mass balance model is coupled to a two-dimensional (2-D) vertically integrated ice-flow model, based on the shallow-ice approximation. Compared to lower-dimensional models, 2-D ice-flow models have no restrictions regarding the spatial distribution of ice; the glacier geometry keeps adapting to changes in the mass balance. This is especially important for ice caps like Hardangerjøkulen, with multiple drainage basins and ice flow in all directions.

Most previous studies with sophisticated mass balance models on glaciers did not consider changes in surface topography (e.g., Klok and Oerlemans, 2002; Gerbaux et al., 2005; Arnold et al., 2006). On the other hand, only few studies investigating the dynamic response of glaciers to a changing climate explicitly calculated a spatially distributed mass balance from meteorological variables. By coupling the mass balance and ice-flow models annually, we compute the response of Hardangerjøkulen to changes in meteorological variables and include feedback mechanisms associated with the interdependence of mass balance and geometry changes.
A similar method has been applied to the ice caps Vatnajökull and Hofjökull in Iceland (Flowers et al., 2005; Aðalgeirsdottir et al., 2006) and Glacier de Saint-Sorlin in the French Alps (Le Meur et al., 2007). The mass balance of the Icelandic glaciers was computed with a degree-day model; Le Meur et al. (2007) used sophisticated atmospheric and snow models.

The main objective of this paper is to determine how Hardangerjøkulen responds to a changing climate. Future climate projections are implemented in a simplified way, to be able to assess the effect of various changes in the meteorological variables and the role of feedback processes. First, we describe the model and the meteorological records used as input to the model. We then compare the modelled and measured energy and mass balance fluxes and demonstrate that the model can reproduce the observed ice cap geometry through the 20th century. We discuss the ice cap volume change for different 21 st century climate projections and show the simulated ice cap geometry for the most probable future climate in more detail. Furthermore, we investigate the importance of feedback processes in the ice cap evolution.

\section{Hardangerjøkulen}

The ice cap Hardangerjøkulen $\left(60.55^{\circ} \mathrm{N}, 7.43^{\circ} \mathrm{E}\right)$ is situated in southern Norway, $150 \mathrm{~km}$ from the western coast (Fig. 1). The present-day ice cap covers $73 \mathrm{~km}^{2}$ and ranges in altitude from 1020 to $1865 \mathrm{~m}$ a.s.l. (Fig. 2). The ice cap geometry was mapped in 1961 and 1995. For the present-day topography, we use the digital elevation model (DEM) for Hardangerjøkulen from 1995, created by the Norwegian Mapping Authority (Statens Kartverk) from aerial photographs.

\subsection{Mass balance}

Annual winter, summer and net mass balances have been measured on the largest, westerly draining outlet glacier Rembesdalsskåka since 1963. The winter balance is usually determined in May, the summer and net balance in early October (Andreassen et al., 2005). The mean annual net mass balance over the period 1963-2005 was slightly positive $(+0.13 \mathrm{~m}$ w.e. - water equivalent), with a mean winter balance of $+2.11 \mathrm{~m}$ w.e. and a mean summer balance of $-1.98 \mathrm{~m}$ w.e. (Kjøllmoen et al., 2006). Based on the mean net mass balance profile for Rembesdalsskåka over the 33 profiles measured between 1965 and 2005, 80\% of the total area of Rembesdalsskåka is located above the mean ELA (1638 m a.s.1.).

\subsection{Automatic weather stations}

Since October 2000, an automatic weather station (AWS) has been in operation in the ablation zone (at $1450 \mathrm{ma}$ a.s.l.) of the north-easterly outlet glacier Midtdalsbreen. This AWS, 
referred to as AWS1, provides all meteorological quantities needed to calculate the local surface energy balance (Giesen et al., 2008). This station was supplemented by a second AWS (AWS2) on the summit of Hardangerjøkulen (1860 $\mathrm{m}$ a.s.l.), which was in operation during the summer of 2005.

\subsection{Glacier length change}

Glacier length change has been measured at Rembesdalsskåka during several intervals, the first measurement dating from 1917. At Midtdalsbreen, glacier length change has been measured annually since 1982 (Andreassen et al., 2005). The length measurements were combined with maps and dated moraines in the glacier forefields to reconstruct glacier length records for the 20th century, used for validation of the coupled model (data provided by H. Elvehøy, NVE, Oslo).

The last major advance of Hardangerjøkulen occurred around AD 1750, in the 'Little Ice Age' (LIA). Figure 2 shows the LIA extent for the north-eastern and southwestern parts of Hardangerjøkulen, determined from terminal moraines (Andersen and Sollid, 1971; Nesje and Dahl, 1991; Nesje et al., 1994; Elvehøy et al., 1997). Since the LIA, Rembesdalsskåka has retreated almost two kilometres, while Midtdalsbreen retreated approximately one kilometre.

\subsection{Ice thickness}

Detailed ice thickness measurements have been done with ground-penetrating radar on Midtdalsbreen (Østen, 1998). In other drainage basins of Hardangerjøkulen, ice thickness was determined along single tracks, and some parts of the ice cap were not covered at all. The thickest ice was found in the central part of Rembesdalsskåka, with a maximum thickness around $380 \mathrm{~m}$.

By assuming perfect plasticity, ice thickness can be estimated from the local surface slope (e.g. Oerlemans, 2001, p. 60). The yield stress needed for these calculations was derived from the detailed ice thickness measurements on Midtdalsbreen, suggesting a value in the range $150-180 \mathrm{kPa}$ (K. Melvold, personal communication, 2009). In addition, a flux balance approach similar to Farinotti et al. (2009) was applied, giving more or less the same ice thickness values. For the unmeasured areas, ice thickness was determined by matching the calculated ice thickness with the available measurements. At ice divides and ice ridges where the surface slope is small, ice thickness was overestimated and manual extrapolation from the measurements was applied. Close to the ice margins, manual extrapolation was also needed to obtain a smooth decrease in ice thickness.

The resulting ice thickness map was combined with the 1995 DEM to derive the bedrock topography (Fig. 2).

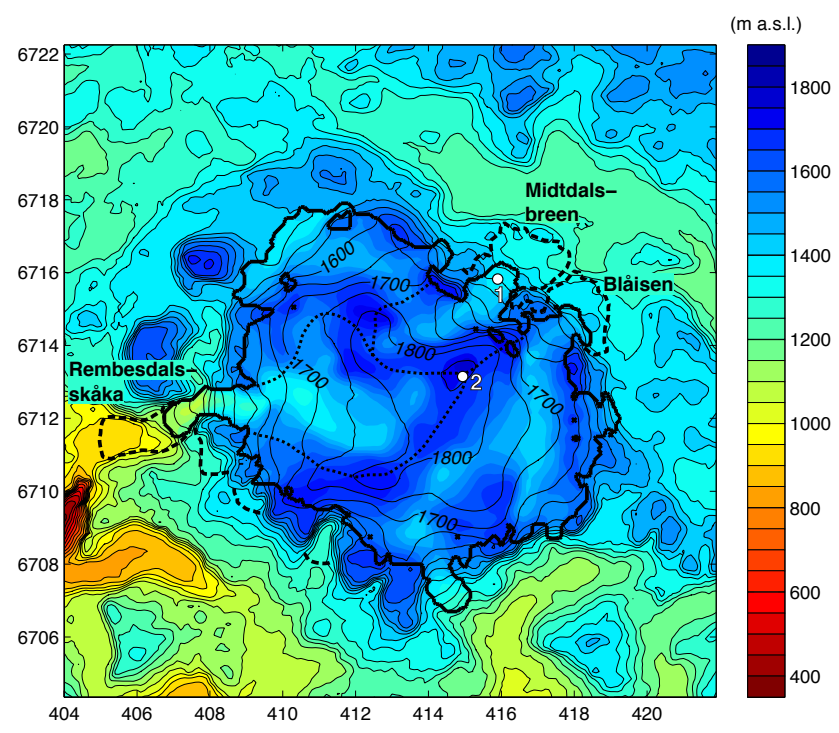

Fig. 2. Present-day surface topography (contours) and bedrock topography (colouring) in the model domain, contours are drawn every $50 \mathrm{~m}$. The thick solid lines indicate the present-day ice cap extent, the thick dashed lines the reconstructed Little Ice Age margin (references in text) and the dotted lines the drainage basins of Rembesdalsskåka and Midtdalsbreen. The locations of the AWSs on Midtdalsbreen (AWS1) and the ice cap summit (AWS2) are indicated by white dots and numbers. The reference system is UTM zone 32 (EUREF89), the tick mark spacing is $2 \mathrm{~km}$.

\section{Model description}

\subsection{Ice-flow model}

We employ an ice-flow model that was previously used to simulate the Eurasian ice sheet through the last glacial cycle (Van den Berg et al., 2008). The model is based on the vertically integrated continuity equation and uses the shallow-ice approximation (SIA; e.g. Hutter, 1983). Since we are interested in the response of the ice cap to mass balance changes over decadal time-scales and the surface and bedrock slopes of Hardangerjøkulen are generally gentle, the SIA can be expected to produce reasonably accurate results (Leysinger Vieli and Gudmundsson, 2004). The vertical mean horizontal velocity $\mathbf{U}$ is divided into contributions by internal deformation $\mathbf{U}_{\mathrm{d}}$ and basal sliding $\mathbf{U}_{\mathrm{s}}$ in the following way (Budd et al., 1979; Oerlemans, 2001):

$$
\begin{aligned}
& \mathbf{U}=\mathbf{U}_{\mathrm{d}}+\mathbf{U}_{\mathrm{s}} \\
& =\left(\rho_{\text {ice }} g\right)^{3} H^{3}\left[\left(\frac{\partial z_{\mathrm{s}}}{\partial x}\right)^{2}+\left(\frac{\partial z_{\mathrm{s}}}{\partial y}\right)^{2}\right] \nabla z_{\mathrm{s}}\left(f_{\mathrm{d}} H^{2}+f_{\mathrm{s}}\right),
\end{aligned}
$$

where $\rho_{\text {ice }}$ is ice density, $g$ the gravitational acceleration, $H$ ice thickness and $z_{\mathrm{s}}(x, y, t)$ surface elevation. The deformation parameter $f_{\mathrm{d}}$ is primarily dependent on ice temperature, the sliding parameter $f_{\mathrm{s}}$ depends on bed roughness and material properties. We use constant values for 
Table 1. Parameter values used in this study. The value for $\Gamma$ listed here is used for extrapolation over the ice cap, for extrapolation of air temperature data to the ice cap, different values are used (Sect. 4.5).

\begin{tabular}{|c|c|c|c|}
\hline Parameter & Symbol & Unit & Value \\
\hline Ice deformation parameter & $f_{\mathrm{d}}$ & $\mathrm{N}^{-3} \mathrm{~m}^{6} \mathrm{~s}^{-1}$ & $7.6 \times 10^{-25}$ \\
\hline Sliding parameter & $f_{\mathrm{S}}$ & $\mathrm{N}^{-3} \mathrm{~m}^{8} \mathrm{~s}^{-1}$ & $9.5 \times 10^{-21}$ \\
\hline Ice density & $\rho_{\text {ice }}$ & $\mathrm{kg} \mathrm{m}^{-3}$ & 900 \\
\hline Snow density & $\rho_{\text {snow }}$ & $\mathrm{kg} \mathrm{m}^{-3}$ & 400 \\
\hline Fresh snow albedo & $\alpha_{\text {frsnow }}$ & & $0.69-0.90$ \\
\hline Firn albedo & $\alpha_{\text {firn }}$ & & 0.53 \\
\hline Ice albedo & $\alpha_{\text {ice }}$ & & 0.35 \\
\hline Bare rock albedo & $\alpha_{\text {rock }}$ & & 0.15 \\
\hline Albedo time-scale & $t_{*}$ & days & 21.9 \\
\hline Albedo depth-scale & $d_{*}$ & mw.e. & 0.001 \\
\hline \multirow[t]{3}{*}{ Thickness subsurface layers } & $\delta z_{1}$ & $\mathrm{~m}$ & 0.1 \\
\hline & $\delta z_{2}$ & $\mathrm{~m}$ & 2.9 \\
\hline & $\delta z_{3}$ & $\mathrm{~m}$ & 7.0 \\
\hline Ice temperature $z_{3}$ at AWS1 & $T_{z_{3}, \mathrm{AWS} 1}$ & $\mathrm{~K}$ & 271.8 \\
\hline Factor in $\tau_{\text {as }}$ equation & $k$ & & 0.972 \\
\hline \multirow[t]{2}{*}{ Factors in $\tau_{\mathrm{cl}}$ equation } & $a_{1}$ & & 0.353 \\
\hline & $a_{2}$ & & 0.124 \\
\hline Clear-sky albedo & $\alpha_{\mathrm{cs}}$ & & 0.064 \\
\hline Clear-sky emissivity of dry air & $\varepsilon_{\mathrm{gh}}$ & & 0.23 \\
\hline Factor in $\varepsilon_{\mathrm{cs}}$ equation & $b$ & $\mathrm{KN}^{-1} \mathrm{~m}^{2}$ & 0.447 \\
\hline Exponent in $\varepsilon_{\mathrm{cs}}$ equation & $m$ & & 8 \\
\hline Overcast sky emissivity & $\varepsilon_{\mathrm{Oc}}$ & & 0.990 \\
\hline Cloud exponent in sky emissivity & $p$ & & 1 \\
\hline $\begin{array}{l}\text { Turbulent exchange coefficient } \\
\text { for the background flow }\end{array}$ & $K_{\mathrm{b}}$ & $\mathrm{ms}^{-1}$ & $0.0046-0.0110$ \\
\hline Threshold temperature for snow & $T_{\text {snow }}$ & $\mathrm{K}$ & 274.55 \\
\hline Temperature lapse rate & $\Gamma$ & $\mathrm{Km}^{-1}$ & 0.0065 \\
\hline Water vapour scaling height & $H_{e}$ & $\mathrm{~m}$ & 2500 \\
\hline Air pressure scaling height & $H_{p}$ & $\mathrm{~m}$ & 8100 \\
\hline
\end{tabular}

both parameters (Table 1), optimized for Hardangerjøkulen by means of a dynamic calibration (Oerlemans, 1997) with the observed length changes at Rembesdalsskåka and Midtdalsbreen. All calibration runs were started in the year 1600, to include the LIA maximum. For computational efficiency, the mass balance distribution used for the dynamic calibration is only dependent on altitude, and was derived from the mean mass balance profile measured on Rembesdalsskåka. For more details on the dynamic calibration procedure, see Giesen (2009), Ch. 6. All spatial derivatives are calculated with central differencing, for the time integration an Alternating Direction Implicit (ADI) method is used (e.g. Huybrechts, 1992). We use a time-step of 0.01 year, which is sufficiently small to exclude numerical instabilities.

\subsection{Surface mass balance model}

The mass balance model only includes mass changes at the surface of the ice cap, basal melting and calving at the glacier front are not included. Currently, the largest outlet glaciers of Hardangerjøkulen do not terminate in water, but Rembesdalsskåka did end in the lake Rembesdalsvatnet when the ice cap was larger (Fig. 2; Elvehøy et al., 1997) and new lakes may form when the ice cap retreats. Basal melt is assumed to be small compared to the high ablation rates at the ice cap surface.

The surface mass balance model is based on a model developed for Morteratschgletscher in Switzerland (Klok and Oerlemans, 2002). The annual surface mass balance $B$ (mw.e.) at each location in the model domain is determined by three processes

$B=\int_{\text {year }}\left[P_{\text {snow }}-M-S\right] \mathrm{d} t$,

where $P_{\text {snow }}$ is the amount of solid precipitation, $M$ is the mass removed by ablation at the surface and $S$ represents mass exchange with the air by sublimation or rime. The surface mass balance is calculated using a time-step of $60 \mathrm{~min}$.

The energy available for melting $Q\left(\mathrm{~W} \mathrm{~m}^{-2}\right)$, is calculated from the surface energy balance:

$Q-G=S_{\text {in }}+S_{\text {out }}+L_{\text {in }}+L_{\text {out }}+H_{\text {sen }}+H_{\text {lat }}$.

$S_{\text {in }}$ and $S_{\text {out }}$ are incoming and reflected solar radiation, $L_{\text {in }}$ and $L_{\text {out }}$ are incoming and outgoing longwave radiation, $H_{\text {sen }}$ and $H_{\text {lat }}$ are the sensible and latent heat fluxes and $G$ is the subsurface heat flux. Heat supplied by rain is neglected, which is justified on glaciers with a considerable mass turnover (Oerlemans, 2001). Fluxes adding energy to the surface layer, both from above and below, are defined positive. When the sum of the fluxes on the right-hand-side of Eq. (3) is positive, this energy is used to heat the surface and underlying snow or ice layers. When the surface temperature has reached the melting point, all excess energy is used to melt snow or ice. The amount of melt $M$ (mw.e.) is calculated from the melting energy $Q$ :

$M=\frac{Q}{L_{\mathrm{f}} \rho_{\mathrm{w}}}$.

with $L_{\mathrm{f}}$ the latent heat of fusion $\left(3.34 \times 10^{5} \mathrm{~J} \mathrm{~kg}^{-1}\right)$ and $\rho_{\mathrm{w}}$ the density of water $\left(1000 \mathrm{~kg} \mathrm{~m}^{-3}\right)$. Sublimation $(S)$ is determined from the latent heat flux

$S=-\frac{H_{\text {lat }}}{L_{\mathrm{s}}} \rho_{\mathrm{w}}$.

where $L_{\mathrm{S}}\left(2.83 \times 10^{6} \mathrm{~J} \mathrm{~kg}^{-1}\right)$ is the latent heat of sublimation. The model only keeps track of changes in solid mass (snow or ice). When the surface is at the melting point, we assume there is meltwater available for vaporization.

Below, we briefly describe the parameterizations used in the energy and mass balance calculations. For details of the used parameterizations, we refer to the cited publications. Parameters in the parameterizations for the surface energy fluxes have been calibrated with data from AWS1. Air temperature, humidity, air pressure and cloud fraction from AWS1 are used as input data for the parameterizations to determine the parameter values giving the best match with measured $S_{\text {in }}$, surface albedo and $L_{\text {in }}$, as well as $H_{\text {sen }}+H_{\text {lat }}$ 
calculated from the AWS data (Giesen et al., 2008). A list of the model parameters and their calibrated values is provided in Table 1. For details of the calibration procedure and the sensitivity of the surface mass balance to the model parameters, we refer to Giesen (2009), Ch. 5.

\subsubsection{Incoming solar radiation}

The seasonal and diurnal variation of incoming solar radiation at the top of the atmosphere are computed with astronomical relations from Iqbal (1983). The transmissivity of the atmosphere for solar radiation is represented by a suite of five transmission coefficients $\tau_{\mathrm{i}}$. For the transmission coefficients after Rayleigh scattering (R), absorption by permanent gases $(\mathrm{g})$ and water vapour $(\mathrm{w})$, and absorption and scattering by aerosols (as), expressions from Meyers and Dale (1983) are used, the cloud transmission coefficient $\tau_{\mathrm{cl}}$ was determined following Greuell et al. (1997). Comparison of modelled incoming solar radiation and the irradiation measured at AWS1 revealed a seasonally varying $\tau_{\mathrm{cl}}$, indicating changing cloud characteristics. Similar to Greuell and Oerlemans (1986), we added a sinusoidally varying term depending on cloudiness. Shading by surrounding topography is computed with algorithms by Dozier and Frew (1990), where shaded grid cells only receive diffuse solar radiation. The total solar radiation impinging on a grid cell is finally multiplied by two factors to account for multiple scattering of the clear sky and reflection of the surrounding slopes; these factors were determined as described by Greuell et al. (1997). Incoming solar radiation is computed twice every hour and averaged for an hourly value. On average, modelled $S_{\text {in }}$ is only $0.2 \mathrm{~W} \mathrm{~m}^{-2}$ larger than the measurements on Midtdalsbreen, with a standard deviation for daily means of $22.6 \mathrm{~W} \mathrm{~m}^{-2}$. Incoming solar radiation measured at AWS2 was not included in the calibration, and is overestimated by the model by $5.4 \mathrm{~W} \mathrm{~m}^{-2}$, with a standard deviation of $36.9 \mathrm{~W} \mathrm{~m}^{-2}$.

\subsubsection{Surface albedo}

Modelled incoming solar radiation is multiplied by the surface albedo to obtain reflected solar radiation. For each grid cell, surface albedo is calculated according to Oerlemans and Knap (1998). In their parameterization, snow ageing is represented as an exponential decrease of the snow albedo from the fresh snow albedo $\alpha_{\text {frsnow }}$ to the firn albedo $\alpha_{\text {firn }}$, controlled by the time-scale $t_{*}$. When snow depth is small, the surface albedo is a function of both snow and ice albedo, according to the depth-scale $d_{*}$.

Compared to surface albedos calculated from incoming and reflected solar radiation at AWS1, the snow albedo computed with this parameterization remains too high in spring, retarding the melt of the snowpack. Modelled albedo improved considerably by making $\alpha_{\text {frsnow }}$ dependent on air temperature during snowfall, which was incorporated in our model in a simple way. When air temperature $T_{\mathrm{a}}$ is lower than $268.5 \mathrm{~K}, \alpha_{\text {frsnow }}=0.90$. For $T_{\mathrm{a}}$ higher than $274.6 \mathrm{~K}$, $\alpha_{\text {frsnow }}=0.69$. Linear interpolation between these two values is used to describe $\alpha_{\text {frsnow }}$ for $T_{\mathrm{a}}$ between 268.5 and $274.6 \mathrm{~K}$. The snow albedo is also set to 0.69 when rain is falling on a snow surface with a higher albedo. These modifications result in a good match with measured snow albedo values and the timing of the ice reappearance at AWS1. Furthermore, the modelled albedo at AWS2 corresponds well to the observed albedo during the 2005 summer season.

The spatial ice albedo distribution over Hardangerjøkulen was examined using three Landsat satellite images taken at 6 August 1988, 21 August 2002 and 15 September 2002 (Giesen, 2004), applying a retrieval method described by Klok et al. (2003). The spatial ice albedo pattern is quite homogeneous, with values generally around 0.35 on the plateau and lower values $(0.30)$ on the glacier tongues. Values below 0.20 are only found in the ice marginal areas. However, there is a large spread $( \pm 0.10)$ between the ice albedos retrieved from the three images. Temporal changes in ice albedo are not included in the model, but appear to be larger than spatial differences. We here use a spatially and temporally constant ice albedo $\alpha_{\text {ice }}$ of 0.35 , which is the mean value for all ice pixels in the three images. Although the estimated uncertainty in $\alpha_{\text {ice }}$ is large $( \pm 0.10)$, the model is not very sensitive to the ice albedo value used; a realistic evolution of the snow albedo and the timing of the ice exposure are much more important.

For non-glaciated grid cells, a bare rock albedo $\alpha_{\text {rock }}$ of 0.15 is prescribed from the moment the winter snowpack has melted.

\subsubsection{Longwave radiation}

Incoming and outgoing longwave radiation are computed from the Stefan-Boltzmann equation.

For incoming longwave radiation, we use the grid cell air temperature and a sky emissivity $\varepsilon_{\text {sky }}$ calculated after Konzelmann et al. (1994)

$\varepsilon_{\mathrm{sky}}=\varepsilon_{\mathrm{cs}}\left(1-n^{p}\right)+\varepsilon_{\mathrm{oc}} n^{p}$.

Here, $\varepsilon_{\mathrm{cs}}$ and $\varepsilon_{\mathrm{oc}}$ are the clear and overcast sky emissivities, respectively and $p$ the cloud exponent. The clear sky emissivity contains a term dependent on the water vapour pressure $e_{\mathrm{a}}$ and a contribution by greenhouse gases other than water vapour $\varepsilon_{\mathrm{gh}}$

$\varepsilon_{\mathrm{cS}}=\varepsilon_{\mathrm{gh}}+b\left(\frac{e_{\mathrm{a}}}{T_{\mathrm{a}}}\right)^{1 / m}$.

For $\varepsilon_{\text {gh }}$ and $m$, we adopted the values provided by Konzelmann et al. (1994) (see Table 1), which are based on calculations with a numerical radiative band model. The values for $b$ and $\varepsilon_{\mathrm{oc}}$ were determined from the best fit with $L_{\text {in }}$ measured at AWS1 during clear-sky and overcast conditions, respectively. Finally, $p$ was determined from measured all-sky $L_{\text {in }}$. 
Measured and modelled $L_{\text {in }}$ for AWS1 are highly correlated because $n$ used to calibrate $L_{\text {in }}$ were first derived from $L_{\text {in }}$, although using a different method (Giesen et al., 2008). For AWS2, modelled $L_{\text {in }}$ is on average $-9.3 \mathrm{~W} \mathrm{~m}^{-2}$ lower than the measurements, with a standard deviation for daily means of $13.4 \mathrm{~W} \mathrm{~m}^{-2}$.

Outgoing longwave radiation was calculated from the surface temperature, assuming that snow and ice emit as a blackbody. The surface temperature is determined with a subsurface model, described in Sect. 3.2.5.

\subsubsection{Sensible and latent heat flux}

Following Klok and Oerlemans (2002), we use a relation by Oerlemans and Grisogono (2002) to determine the turbulent fluxes from free-atmosphere variables:

$H_{\text {sen }}=\rho_{\mathrm{a}} c_{p}\left(K_{\mathrm{kat}}+K_{\mathrm{b}}\right)\left(T_{\mathrm{a}}-T_{\mathrm{s}}\right)$

$H_{\text {lat }}=0.622 \rho_{\mathrm{a}} L_{\mathrm{s}}\left(K_{\text {kat }}+K_{\mathrm{b}}\right)\left(e_{\mathrm{a}}-e_{\mathrm{s}}\right) / p_{\mathrm{a}}$,

where $\rho_{\mathrm{a}}$ is air density, $c_{p}$ the specific heat of dry air and $K_{\text {kat }}$ and $K_{\mathrm{b}}$ the turbulent exchange coefficients for katabatic flow and the background flow, respectively. $T_{\mathrm{a}}$ and $T_{\mathrm{S}}$ are the air and surface temperatures, $e_{\mathrm{a}}$ and $e_{\mathrm{S}}$ the air and surface water vapour pressures and $p_{\mathrm{a}}$ the air pressure. The turbulent exchange coefficients represent the combined influence of wind speed and surface roughness on the turbulent exchange. Klok and Oerlemans (2002) computed $K_{\text {kat }}$ after Oerlemans and Grisogono (2002) and used a constant value for $K_{\mathrm{b}}$. By doing so, they assumed that wind speed increases when a katabatic wind develops. On Midtdalsbreen, wind speeds induced by the large-scale flow are generally much larger than katabatic winds. Furthermore, wind speeds are significantly higher under overcast skies (Giesen et al., 2008). To include these characteristics in the model, we removed $K_{\text {kat }}$ and use a variable $K_{\mathrm{b}}$ dependent on cloudiness. Based on the data from AWS $1, K_{\mathrm{b}}$ is taken constant $\left(0.0046 \mathrm{~m} \mathrm{~s}^{-1}\right)$ for $n=0$, increasing linearly with cloudiness to values varying between $0.0074 \mathrm{~m} \mathrm{~s}^{-1}$ (July) and $0.0110 \mathrm{~m} \mathrm{~s}^{-1}$ (January) for $n=1$. With our parameterization, the sum of modelled $H_{\text {sen }}$ and $H_{\text {lat }}$ is on average $1.8 \mathrm{~W} \mathrm{~m}^{-2}$ larger than the measured flux values, with a standard deviation for daily mean values of $16.3 \mathrm{~W} \mathrm{~m}^{-2}$.

\subsubsection{Subsurface processes}

Similar to Klok and Oerlemans (2002), we compute the subsurface heat flux and the surface temperature by determining the heat conduction in a simple three-layer subsurface model. For the upper, second and third layer of the subsurface model we used layer thicknesses of $\delta z_{1}=0.1 \mathrm{~m}$, $\delta z_{2}=2.9 \mathrm{~m}$ and $\delta z_{3}=7.0 \mathrm{~m}$, respectively. The lowest layer has a constant temperature. At the AWS1 altitude, we set the temperature of this layer to the deep-ice temperature calculated from the AWS1 data $\left(T_{z_{3}}, \mathrm{AWS} 1=271.8 \mathrm{~K}\right.$; Giesen et al., 2008).
Refreezing of rain and meltwater in the snowpack is not included in the model. Ice formation has been observed in Hardangerjøkulen's accumulation area (Laumann, 1972), mainly in the form of ice lenses. Water that refreezes needs to be melted again, but on the other hand raises the snowpack temperature and lowers the albedo. The available measurements are insufficient to determine the net effect of refreezing on the mass balance. Considering that substantial ablation occurs even at the highest altitudes $\left(1-2 \mathrm{~m}\right.$ w.e. $\mathrm{a}^{-1}$ according to the mass balance measurements), the amount of energy needed to heat the snowpack to the melting temperature is much smaller (5\% at maximum) than the total energy available during the summer season. We therefore expect the effect of refreezing on the mass balance to be small.

\subsubsection{Extrapolation over the model domain}

To compute the surface energy fluxes at each grid cell, air temperature, deep-ice temperature, relative humidity, air pressure and cloudiness at AWS1 need to be extrapolated over the model domain. For air temperature and deep-ice temperature, we use a constant lapse rate of $\Gamma=6.5 \mathrm{~K} \mathrm{~km}^{-1}$. The mean air temperature difference between AWS1 and AWS2 over the summer of 2005 gives a lapse rate of $6.7 \mathrm{~K} \mathrm{~km}^{-1}$; the value $6.5 \mathrm{~K} \mathrm{~km}^{-1}$ was reported by Green and Harding (1980) and is often used in studies by the Norwegian Meteorological Institute (e.g. Hanssen-Bauer et al., 2003). Applying this lapse rate to air temperatures measured at AWS1, the difference between mean modelled and measured $T_{\mathrm{a}}$ at AWS2 is smaller than $0.01 \mathrm{~K}$, with a standard deviation for daily means of $0.54 \mathrm{~K}$. Relative humidity at the AWS1 altitude is converted to water vapour pressure, for both water vapour and air pressure an exponential decrease with altitude is prescribed with scaling heights derived from the two AWS records (Table 1). We assume that the cloud fraction does not vary over the model domain.

Compared to the mean summer mass balance profile computed from 33 profiles measured by NVE, modelled ablation was too low at altitudes above approximately $1650 \mathrm{~m}$ a.s.l. Because the correspondence between measured and modelled incoming solar radiation, surface albedo and air temperature at the summit is good, too small turbulent fluxes at the plateau are a probable cause for this underestimation. Measurements at AWS2 indicate higher wind speeds at the summit than at AWS1 on Midtdalsbreen. To obtain a better match between modelled and measured ablation at the ice cap plateau, we let the turbulent exchange coefficient increase linearly by a factor of 1.2 per $100 \mathrm{~m}$ altitude interval above $1650 \mathrm{~m}$ a.s.l. 
Table 2. NMI weather station information and overview of the data used as model input. Data from Voss Bø, Eidfjord Bu and Liset were used to supplement the records from the principal stations Slirå, Finse and Finsevatn, as described in the text. The distance given is the approximate distance to the centre of Hardangerjøkulen. The meteorological variables are indicated as $T_{\mathrm{a}}$ (air temperature), RH (relative humidity), $p_{\mathrm{a}}$ (air pressure), $n$ (cloudiness) and $P$ (precipitation).

\begin{tabular}{lrrrlr}
\hline Station name & WMO nr. & $\begin{array}{r}\text { Altitude } \\
(\mathrm{m} \text { a.s.l. })\end{array}$ & $\begin{array}{r}\text { Distance } \\
(\mathrm{km})\end{array}$ & $\begin{array}{l}\text { Meteorological } \\
\text { variables }\end{array}$ & Period \\
\hline Bergen & 50560 & 41 & 120 & $T_{\mathrm{a}}, P$ & $1905-1984$ \\
$\begin{array}{l}\text { Fredriksberg } \\
\text { Bergen }\end{array}$ & 50540 & 12 & 120 & $T_{\mathrm{a}}, P$ & $1985-2005$ \\
Florida & & & & & \\
Slirå & 25900 & 1300 & 9 & $T_{\mathrm{a}}, \mathrm{RH}, p_{\mathrm{a}}, n, P$ & $1958-1969$ \\
Finse & 25840 & 1224 & 8 & $T_{\mathrm{a}}, \mathrm{RH}, n, P$ & $1970-1993$ \\
Voss B $\varnothing$ & 51590 & 125 & 55 & $p_{\mathrm{a}}$ & $1968-2002$ \\
Finsevatn & 25830 & 1210 & 9 & $T_{\mathrm{a}}, p_{\mathrm{a}}$ & $1994-2005$ \\
Eidfjord Bu & 49580 & 165 & 35 & $T_{\mathrm{a}}, \mathrm{RH}, n$ & $1978-2005$ \\
Liset & 49750 & 748 & 15 & $P$ & $1974-2005$ \\
\hline
\end{tabular}

\subsubsection{Precipitation}

Precipitation is assumed to fall as snow when $T_{\mathrm{a}}$ is below $1.4^{\circ} \mathrm{C}$. This value was reported from meteorological measurements on Rembesdalsskåka in the summer of 1965 (Pytte and Liestøl, 1966).

As a result of the prevailing south-westerly winds and the mountain chain along the Norwegian west coast, annual precipitation quickly decreases from the coast to the inland areas (e.g., Østrem et al., 1988; Giesen et al., 2009). This gradient is also expected to be present over Hardangerjøkulen; annual precipitation at meteorological stations south-west of the ice cap is significantly higher than at stations north and east of Hardangerjøkulen. However, measurements on and around the ice cap are too sparse to derive a sophisticated precipitation gradient. Based on the annual precipitation received at two meteorological stations on opposite sides of the ice cap (Liset and Finse, Sect. 4.1 and Table 2), we impose a linear south-west-north-east (SW-NE) precipitation gradient over the ice cap. Precipitation decreases by $0.50 \% \mathrm{~km}^{-1}$ in both easterly and northerly directions, corresponding to a maximum gradient of $0.71 \% \mathrm{~km}^{-1}$ in the SW-NE direction.

Superimposed on the horizontal gradient described above, we prescribe an altitudinal gradient in precipitation according to 33 measured winter balance profiles on Rembesdalsskåka. An altitude-dependent multiplication factor was derived from the mean modelled and measured winter accumulation profiles. We use a second-order polynomial for altitudes below $1700 \mathrm{~m}$ a.s.l. and multiply this polynomial with another second-order polynomial for higher altitudes, where precipitation increases more slowly or even decreases with altitude (Fig. 3). With this vertical gradient, the mean modelled winter balance over the 33 years with winter balance profiles available corresponds well to the mean measured profile, especially above $1600 \mathrm{~m}$ a.s.l. At lower

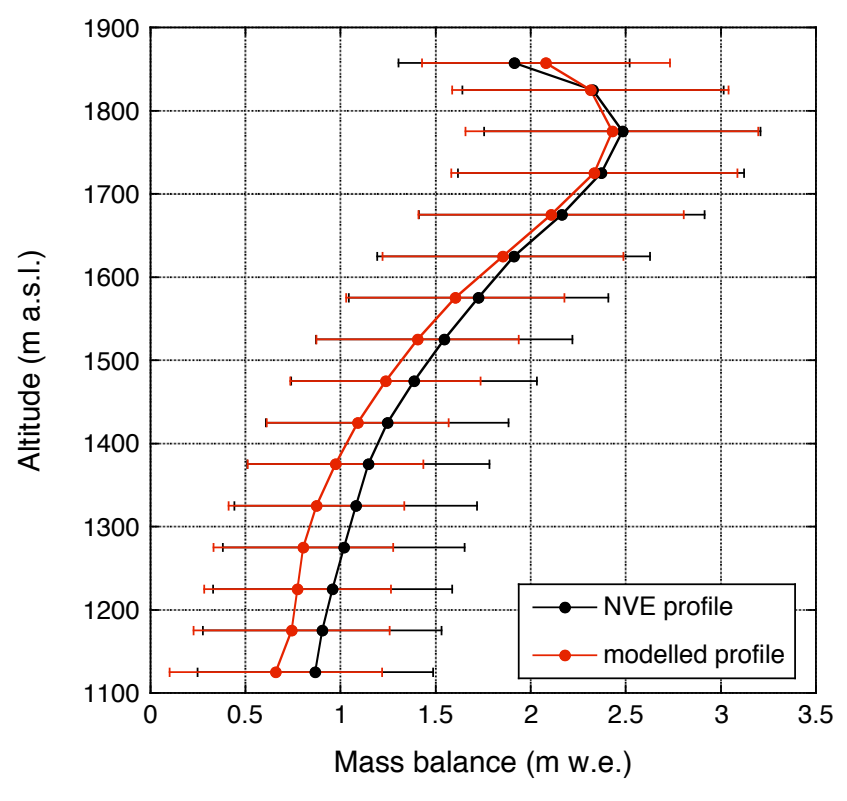

Fig. 3. Altitudinal profiles of the mean measured and modelled winter mass balance for Rembesdalsskåka for 33 years in the period 1963-2005. The modelled profile is calculated with local meteorological data (Sect. 4.1). The error bars represent one standard deviation, computed from the 33 annual profiles.

elevations, the winter balance is underestimated by approximately $0.2 \mathrm{~m}$ w.e. This larger difference could be due to a larger uncertainty in the measurements. Above $1500 \mathrm{~m}$ a.s.l., the observed winter balance is based on sounding profiles, while often only one stake is used to determine the winter balance on the glacier tongue. Because less than $10 \%$ of the total ice cap area is situated below $1500 \mathrm{~m}$ a.s.l., the larger uncertainty in the precipitation at these elevations has a minor effect on the area-averaged winter balance. On the 
glacier tongue, the multiplication factor is constant and the winter balance only increases with altitude due to decreasing air temperature. This constant multiplication factor is also used at altitudes lower than the minimum altitude of Rembesdalsskåka. Using a simple parameterization based on the altitudinal profiles from Rembesdalsskåka alone will certainly result in errors in the spatial precipitation distribution on the other outlet glaciers and on Rembesdalsskåka itself. However, the precipitation per altitude interval will be reasonable for Rembesdalsskåka, which is the largest outlet glacier and covers $32 \%$ of the area above $1700 \mathrm{~m}$ a.s.l.

\subsection{The coupled model}

All calculations are performed on a $18 \times 18 \mathrm{~km}^{2}$ model domain with a horizontal resolution of $100 \mathrm{~m}$. Model years are shifted with respect to calendar years and run from 1 October in the previous year to 30 September in the corresponding calendar year. In this way, a model year approximates one mass balance year, consisting of an accumulation season and the following ablation season. Since we use constant deformation and sliding parameters in the ice-flow model, seasonal variations in the ice flow cannot be modelled. This is not a problem, because we are only interested in the longterm evolution of Hardangerjøkulen. For the same reason, it is not necessary to couple the models at sub-annual timescales, as long as the time-scale is much shorter than the response time of the ice cap. We therefore compute the annual surface mass balance on a fixed grid and supply the resulting mass balance field to the ice-flow model to compute the ice thickness changes induced by the annual mass balance. The updated surface topography and ice cap extent are returned to the mass balance model to start the calculations for the next year. At the beginning of each mass balance year, new surface slope, aspect and horizon angles are computed from the updated surface topography and used in the radiation calculations. We assume that the typical shape of the altitudinal precipitation profile is primarily resulting from the plateau geometry and less from its absolute elevation. We therefore let the maximum in the precipitation profile change along with variations in the summit elevation. In the same way, the altitude above which we prescribe an increase in the turbulent exchange coefficient ( $1650 \mathrm{~m}$ a.s.l. for the present-day geometry) is adjusted to keep its vertical distance from the summit constant.

\section{Meteorological input data}

\subsection{Local stations (1957-2005)}

From 1957 onwards, digitized data from weather stations in the vicinity of Hardangerjøkulen $(<60 \mathrm{~km}$ distance $)$ are available from the Norwegian Meteorological Institute (NMI; see Fig. 1 and Table 2). Since none of the stations have data records spanning the entire period of interest (19572005), we had to use a combination of records from different stations. This combined dataset is referred to as "local" data in the following. The meteorological records from stations in the vicinity of the ice cap have not been thoroughly tested for inhomogeneities and biases, but were inspected for outliers and compared to records from other stations to identify regional differences in meteorological conditions.

Whenever possible, we use records from the nearest station, located north of Hardangerjøkulen. This station was relocated and renamed two times during the period considered, subsequently being called Slirå (1957-1969), Finse (19701993) and Finsevatn (1994-2005). Slirå and Finse were manned stations, Finsevatn is an automatic weather station. At Slirå, all input meteorological variables were measured. Air pressure was not measured at Finse, for which we use data from Voss B $\emptyset$. From Finsevatn we only use air temperature and air pressure measurements, the relative humidity and precipitation records contain large gaps and are unreliable. Cloudiness was not measured at Finsevatn. Precipitation was taken from measurements at Liset, which despite its location on almost the opposite side of Hardangerjøkulen, has a very similar interannual variability in winter precipitation as Slirå and Finse. For the overlap period 1974-1993, the correlation coefficient of annual November-March precipitation at Finse and Liset is 0.97. From 1994 onwards, we use relative humidity and cloud fraction observations from Eidfjord $\mathrm{Bu}$. Compared to Slirå and Finse, Eidfjord Bu is located far from Hardangerjøkulen. Still, for the overlapping period (1978-1994), the cloud fractions measured at Eidfjord $\mathrm{Bu}$ and Finse have a linear correlation coefficient $r=0.75$, the frequency distribution is similar and the mean cloud fraction is equal. Air temperature measured at Eidfjord $\mathrm{Bu}$ is used to convert the relative humidity measurements to water vapour pressure. At Liset, precipitation is measured once a day at 06:00 UTC, at Slirå and Finse measurements were made at 06:00 and 18:00 UTC. The other variables were measured at 06:00, 12:00 and 18:00 UTC, sometimes measurements made at 00:00 or 09:00 UTC were reported. Hourly data are available for Finsevatn.

\subsection{Bergen (1904-2005)}

Before 1957, the nearest synoptic station with available data is the NMI station in Bergen (Fig. 1 and Table 2), located approximately $120 \mathrm{~km}$ west of Hardangerjøkulen. We use records from 1904 onwards, when measurements were started at Bergen Fredriksberg, measurements from Bergen Florida are used from 1985 onwards. The meteorological records from Bergen have been homogenized and bias corrected by the NMI. For the period 1904-1949, only measurements of air temperature, relative humidity and precipitation are available. After 1950, additional meteorological variables are available for Bergen, but we only use air temperature, relative humidity and precipitation for the entire 
period until 2005. In this way, the performance of the model with the limited data set from Bergen can be compared to results with the more extensive input data set from the local weather stations. Air temperature and relative humidity were measured at 06:00, 12:00 and 18:00 UTC. For Bergen Florida measurements at 00:00 UTC are also available, the frequency increasing to 3-hourly data in 1996 and hourly data in 1998. Precipitation was measured twice a day (06:00 and 18:00 UTC).

\subsection{Control climate (1961-1990)}

The climate over the period 1961-1990 was determined from the local meteorological data to serve as a basis for future climate projections. The climatological annual cycle was simply defined as the 30 year average for each daily or hourly interval as used in the model. Compared to the local meteorological records for the AWS1 period (2001-2005), the mean summer temperature (June-August) for 1961-1990 was about $1{ }^{\circ} \mathrm{C}$ lower, while winter precipitation (NovemberMarch) was approximately $15 \%$ lower.

\subsection{The RegClim projections (2071-2100)}

To compute future mass balances, we apply climate projections for southern Norway from the RegClim project (http:// regclim.met.no). These projections are based on downscaled results from the atmosphere-ocean general circulation models ECHAM4/OPYC3 (Roeckner et al., 1999) and HadCM3 (Gordon et al., 2000), using the SRES A2 and B2 scenarios (Nakicenovic et al., 2000). The projected changes in meteorological variables depend on the choice of the emission scenario, the climate model and the downscaling method. We therefore use a number of projections as input to the model, to determine the variability in the ice cap response to different climate changes. The climate projections give the change in air temperature, precipitation, cloudiness, air pressure and wind speed from the normal period 1961-1990 to 20712100. For the area around Hardangerjøkulen, the RegClim results indicate an increase in the annual mean temperature $(\Delta T)$ of approximately $3{ }^{\circ} \mathrm{C}$ from $1961-1990$ to $2071-2100$, with the largest changes in autumn and winter. Annual precipitation will probably increase by approximately $10 \%$, although an increase of $\Delta P=70 \%$ was projected by one of the models (Räisänen et al., 2004). The projected increase in autumn and winter precipitation is larger than $10 \%$, while summer precipitation may decrease. Since the net mass balance on Hardangerjøkulen is probably more sensitive to temperature changes in summer and precipitation changes in winter, we investigate the effect of a seasonal cycle in the climate projections compared to annual changes. The projected air pressure change is smaller than $\pm 5 \mathrm{hPa}$, which is too small to have a notable effect on the calculated mass balance and is therefore not further examined. Cloudiness is projected to change by less than $5 \%$ in all seasons. For present-day conditions, the effect of cloud changes on solar radiation is approximately compensated by a change in longwave radiation of the opposite sign. In a warmer climate, the balance between incoming longwave and solar radiation may change and the effect of cloud fraction changes may be different. We therefore investigate the effect of a $5 \%$ increase in the cloud fraction in combination with a temperature increase. The projected wind speed change is within $\pm 6 \%$, but the effect of such a change cannot be easily determined because wind speeds are incorporated in the turbulent exchange coefficient. By increasing the turbulent exchange coefficient by $10 \%$ along with a temperature increase, we use the model to obtain a rough estimate of the wind speed dependence of the surface mass balance.

\subsection{Implementation in the model}

\subsubsection{Observational records}

Since we use mass balance years instead of calendar years, the first model year starts at 1 October of the first year with available meteorological data. Hence, model runs are performed for the mass balance years 1958-2005 and 19052005 with the local and Bergen input data sets, respectively.

When air temperature measurements were available for three-hourly intervals, measurements were linearly interpolated to obtain hourly input data. For data sets with three or four measurements per day, the daily cycle was approximated by a sine function fitted through the available measurements. Seasonally varying lapse rates for temperature are necessary to correct for differences in the boundary-layer structure at the meteorological station and the glacier surface (Giesen et al., 2009). To calculate the air temperature at the AWS1 altitude, separate lapse rates are applied for the local and Bergen data, determined from the difference in monthly mean values between the input data and the AWS1 measurements for the period 2001-2005. In the winter months, lapse rates derived from local data show a large spread and we set the lapse rate to $6.5 \mathrm{~K} \mathrm{~km}^{-1}$. Values up to $9.7 \mathrm{~K} \mathrm{~km}^{-1}$ were obtained for local data in summer, caused by the cooling effect of the glacier surface and enhanced heating at the valley station. As the local stations are situated within the altitude range of the ice cap, erroneous lapse rates introduce a relatively small error. Monthly lapse rates derived from the Bergen data have a much smaller spread and range between 6.4 and $7.5 \mathrm{~K} \mathrm{~km}^{-1}$. Modelled and measured daily air temperatures at AWS1 for the period 2001-2005 are highly correlated, $r=0.94$ and $r=0.93$ with data from Finsevatn and Bergen, respectively. Relative humidity measurements were linearly interpolated between measurement times to create an hourly input data set. Air pressure input data were not interpolated to obtain hourly values, we only calculate the air pressure field at the measurement times. For the model runs with data from Bergen, we prescribe a seasonally varying air pressure at the AWS1 altitude with a sine function, 
based on the AWS1 measurements. The cloud fraction input data were linearly interpolated between measurement times to create an hourly input data set. For runs with the Bergen data set, we prescribe the cloud fraction with a seasonally varying sinusoidal function derived from the AWS1 measurements. The daily precipitation sum from the input data is distributed evenly over the day in the model. As the measurement period at the NMI stations does not coincide with a calendar day, we prescribe the precipitation sum measured until 06:00 UTC the following day on the first day, hence the record is shifted $6 \mathrm{~h}$ backward. For each precipitation data set (Slirå, Finse, Liset and Bergen), we determined a multiplication constant to relate measured precipitation to accumulation at the ice cap by fitting modelled to measured annual winter balance on Rembesdalsskåka for all overlapping years. In this way, the total amount of winter accumulation is constrained to the measured winter balance, but interannual variations are preserved. Precipitation from Slirå and Finse is multiplied by 0.5 whenever the station temperature is above the threshold temperature for snow (Table 1), to correct for overestimated values in summer resulting from snow undercatch in winter.

\subsubsection{Climate projections}

All investigated future climate projections are incorporated in the same way in the model. Since the projections are defined as the change from the normal period 1961-1990 to 2071-2100, we assume a linear increase/decrease of the considered meteorological variable by the projected amount from the middle of the first period (1976) to the middle of the second period (2086). As meteorological measurements are available until 2005, the climatological data are used from 2006 onwards. Hence, at the beginning of the 21 st century simulation (2006), a 30/110th fraction of the imposed climate change is supposed to have already occurred. We determine the effect of various changes in annual temperature, as well as the combination of the most probable temperature increase $\left(3^{\circ} \mathrm{C}\right)$ with different increases in precipitation. The largest increase in both temperature and precipitation is projected for autumn and winter, but the timing of the maximum and minimum varies for the different climate models and scenarios. We therefore examine the effect of a sinusoidal variation with the maximum in mid-autumn (15 October) and the minimum in mid-spring, as well as a sinusoidal variation with the maximum in mid-winter (15 January) and the minimum in mid-summer. The amplitude of the oscillation was estimated from the RegClim results; air temperature is varied by $\pm 0.6^{\circ} \mathrm{C}$ from a mean change of $+3.0^{\circ} \mathrm{C}$ and precipitation is varied by $\pm 15 \%$ from a mean change of $+10 \%$.

\section{Results}

In order to simulate the ice cap response to future climate projections, the model should simulate the present-day surface energy and mass balance properly. Therefore, we first compare the modelled surface energy and mass balances with the AWS1 measurements and the mass balance measurements on Rembesdalsskåka. Ice dynamical effects are excluded in these model runs by keeping the surface topography fixed at the 1995 DEM. Subsequently, ice dynamics are included and we show the modelled response of Hardangerjøkulen to the observed climate of the 20th century and various climate scenarios for the 21 st century.

\subsection{Surface energy balance at AWS1}

The seasonal cycle of the surface energy balance at AWS1 is well captured by the model (Fig. 4a). Of course, the parameterizations for the surface energy fluxes were calibrated with the AWS1 measurements, but this calibration was performed with the meteorological records from AWS1, while the energy fluxes shown in Fig. 4a were calculated with local meteorological data. The model generally overestimates $S_{\text {net }}$, while $L_{\text {net }}$ is too negative, which may indicate that cloud conditions at the local station are slightly different from the AWS1 site.

For the period 1961-1990, all modelled energy fluxes are smaller than for the warm 2001-2005 period (Fig. 4b). Using the control climate instead of the local meteorological records results in higher net solar radiation in several months; for the other fluxes the differences are small.

All surface energy fluxes increase or become less negative when the air temperature is raised by $3{ }^{\circ} \mathrm{C}$, except for $G$, which remains close to zero (Fig. $4 \mathrm{c}$ ). Because the winter snowpack with a high albedo disappears earlier in spring, the maximum in $S_{\text {net }}$ occurs earlier in the season and the largest increase in melt energy is simulated for June. The increase in $Q$ in the other summer months is mainly a result of larger turbulent fluxes and a small positive contribution by $L_{\text {net }}$. Besides the increase in melt energy, the melt season also becomes slightly longer. Almost no change in the surface energy fluxes is modelled in winter, because the surface temperature increases along with the air temperature, as long as it is lower than the melting point temperature. Again, there are only minor differences between the seasonal cycles modelled with the local data and the control climate.

This simulation shows how the surface energy fluxes at AWS1 are affected by an instantaneous temperature increase. For the future projection of Hardangerjøkulen, the air temperature is assumed to increase linearly in time and the ice cap surface will have lowered with respect to the 1995 DEM by the time the temperature has risen by $3{ }^{\circ} \mathrm{C}$. The dynamic response will thereby further amplify the effect of the warming on the surface energy balance. 

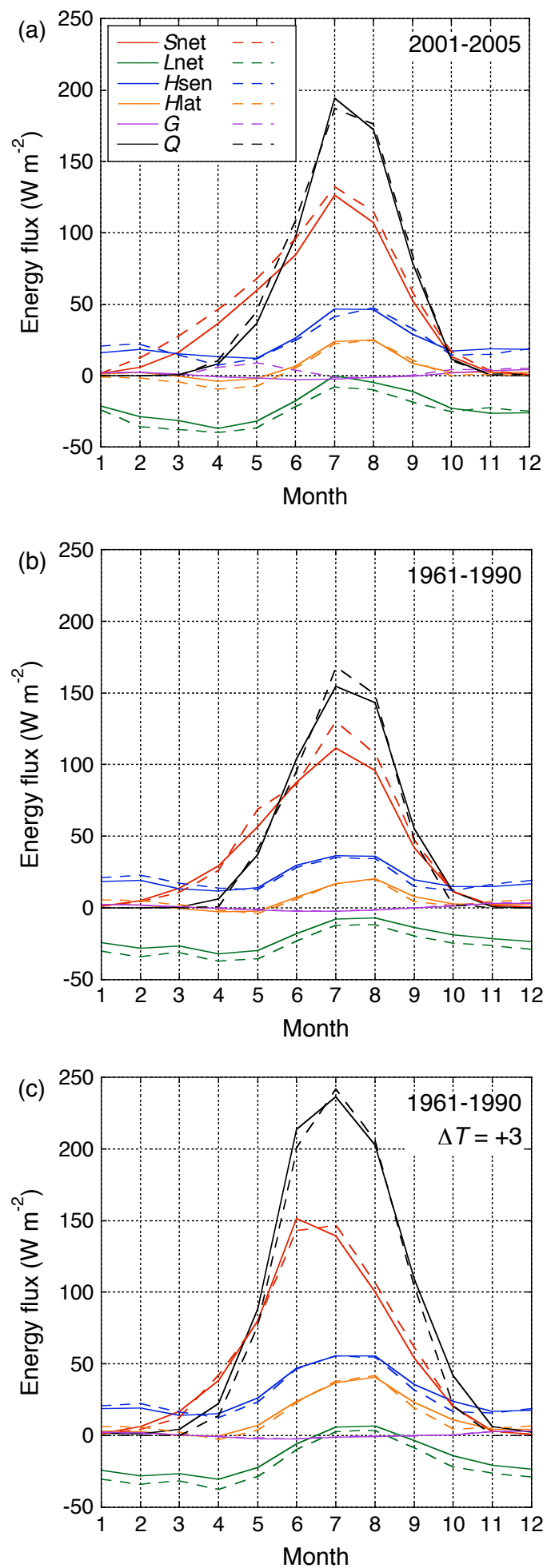

Fig. 4. Seasonal cycle of the surface energy fluxes at AWS1, modelled with the local meteorological records (solid lines) for (a) 2001-2005, (b) 1961-1990 and (c) 1961-1990 with $\Delta T=+3{ }^{\circ} \mathrm{C}$. The dashed lines in (a) show the mean seasonal cycle of the AWS1 measurements for the same period, in (b) and (c) they show the results of simulations with the control climate for 1961-1990.
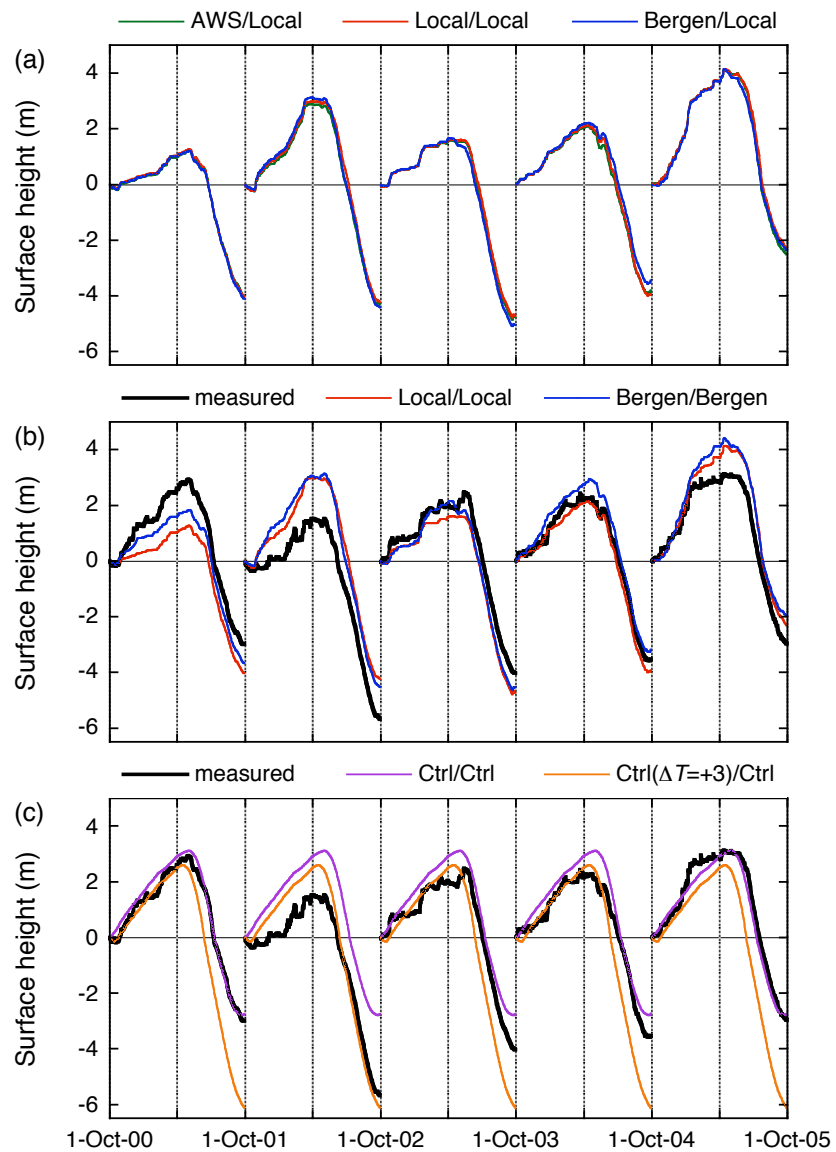

Fig. 5. Modelled surface height at AWS1 using various meteorological input data sets. The legend indicates the data set used; a deviating name after the slash (/) implies that a different precipitation record is used, as explained in the text. (a) All simulations with local precipitation, (b) precipitation record from the corresponding data set, and (c) the control climate ( $\mathrm{Ctrl})$ and the control climate with a $3{ }^{\circ} \mathrm{C}$ higher temperature. In (b) and (c) the measured surface height is also shown.

\subsection{Accumulation and ablation at AWS1}

In this section, we compare accumulation and ablation modelled with AWS1 data, local input data, Bergen data and the control climate to the measurements at AWS1. Differences between the precipitation records, and hence winter accumulation, complicate the comparison of ablation computed with the different data sets. We therefore distinguish between the effect of precipitation records and the effect of the other meteorological records (air temperature, relative humidity, air pressure and cloudiness) from different sources on the modelled mass balance. This is done by first using the same (local) precipitation record in all runs and only changing the set with the remaining four meteorological variables. Similar results are obtained in the three runs (Fig. 5a), hence modelled ablation at AWS1 does not deteriorate when meteorological observations from locations outside the ice cap are 
Table 3. Linear correlation coefficient $r$ and the mean annual difference between modelled and measured winter, summer and net mass balance $\Delta B$ (mw.e.) for Rembesdalsskåka over the period 1963-2005.

\begin{tabular}{lcccccc}
\hline & \multicolumn{2}{c}{ winter } & \multicolumn{2}{c}{ summer } & \multicolumn{2}{c}{ net } \\
& $r$ & $\Delta B$ & $r$ & $\Delta B$ & $r$ & $\Delta B$ \\
\hline Local, $z_{\mathrm{s}}$ DEM & 0.92 & -0.06 & 0.75 & +0.05 & 0.88 & -0.01 \\
Local, $z_{\mathrm{s}}$ model & 0.91 & -0.05 & 0.75 & +0.04 & 0.88 & -0.01 \\
Bergen, $z_{\mathrm{s}}$ DEM & 0.82 & -0.04 & 0.74 & +0.19 & 0.85 & +0.15 \\
Bergen, $z_{\mathrm{s}}$ model & 0.81 & -0.01 & 0.75 & +0.19 & 0.85 & +0.18 \\
\hline
\end{tabular}

used; provided that the differences between these locations and AWS1 are accounted for by a careful calibration.

The variability between the mass balance calculated with different data sets increases when the precipitation records are varied along with the other records (Fig. 5b). The difference with measured snow depth is large in three of the five years, leading to the largest deviations from measured net ablation in these years. In 2003 and 2004, modelled snow depth is similar to the observed snow depth and measured net ablation is better reproduced. The modelled start of the melt season and the changes in ablation rate through the summer season agree well with the observations, again confirming that the modelled energy fluxes are realistic and the differences with observations primarily originate from differences in precipitation. Although the differences between model results and measurements are large in individual years, the observed net ablation after five years is exactly reproduced with the local meteorological data, while it is underestimated by $8 \%$ with the Bergen data.

When the surface topography is not allowed to change, the accumulation and ablation modelled with the control climate are by definition the same for all years. The comparison with measured surface height changes illustrates that the modelled start and end of the ablation season correspond well to the measurements (Fig. 5c). For a $3{ }^{\circ} \mathrm{C}$ higher air temperature, the largest change occurs in the ablation season; the winter accumulation commences about 15 days later than with the control climate, but the temperature in the winter months remains below the threshold temperature for snow. Compared to the control climate, ice melt increases by almost $3.5 \mathrm{~m}$ and closely resembles the measured ablation in the warm summer of 2002 (Giesen et al., 2008).

\subsection{Comparison with mass balance measurements}

Modelled winter, summer and net mass balance for Rembesdalsskåka are compared with NVE measurements (Sect. 2.1) for all 43 individual years (Fig. 6). For the input data from both local stations and Bergen, the overall agreement between model results and measurements is good. The highest correlation coefficients are obtained for the winter and net balance (Table 3), the interannual variability in the summer balance appears to be more difficult to simulate with the model. The best correlation is obtained by using local input data; with Bergen input data, the winter balance is underestimated in the four wettest years. This could imply that the precipitation anomaly in the surroundings of Hardangerjøkulen is larger than in Bergen. The mean annual summer balance modelled with Bergen input data is $0.19 \mathrm{~m}$ w.e. greater than the measured value, resulting in a higher than observed net balance in most of the years. Considering that cloud observations were not used in the simulations with data from Bergen, the model results are remarkably close to the measured values. There is little difference between the mass balance values modelled with either a constant or a responding surface topography, suggesting that the modelled surface topography does not deviate much from the 1995 DEM. A comparison of two DEMs from 1961 and 1995 indicates that elevation changes over Rembesdalsskåka generally ranged between -2 and $+15 \mathrm{~m}$ (Andreassen and Elvehøy, 2001).

For all 33 years with an altitudinal mass balance profile available from NVE measurements, we compared the measured and modelled ELA. The mean modelled ELA, derived from the mean net mass balance profile for Rembesdalsskåka, is $19 \mathrm{~m}$ higher than the measured value (1638 m a.s.1.), mainly due to slightly different shapes of the modelled and measured profiles. At altitudes below the ELA, the measured profile is based on a limited number of stakes (only two in recent years) and the uncertainty in the interpolated profile is larger. In the period 1963-2005, there were six years with a reported ELA above the ice cap summit. Modelled mass balances are negative for the entire ice cap in seven years, of which four years match with observed ELAs above the ice cap summit. For all years with both observed and modelled ELAs below the ice cap summit, the modelled ELA is on average $23 \mathrm{~m}$ higher, with a standard deviation of $60 \mathrm{~m}$.

We already showed that simulations with the control climate can reproduce the seasonal cycle in the energy and mass balance as measured at AWS1. The control climate precipitation data were multiplied by a factor of 0.96 to match the modelled winter balance with the mean value from the NVE measurements over the period 1963-1990. The modelled summer and net mass balance were not scaled in any way and correspond well to the mean NVE values, the difference is less than $\pm 0.01 \mathrm{~m}$ w.e.

\subsection{Spatial distribution of the surface mass balance}

Figure 7 illustrates the spatial pattern of the modelled net mass balance for the present-day topography (1995 DEM), together with the mass balance deviation from the altitudinal mean. These deviations reveal spatial patterns arising from other processes than altitudinal gradients in meteorological variables, e.g. topographic shading and the horizontal precipitation gradient. We here show the mean annual 

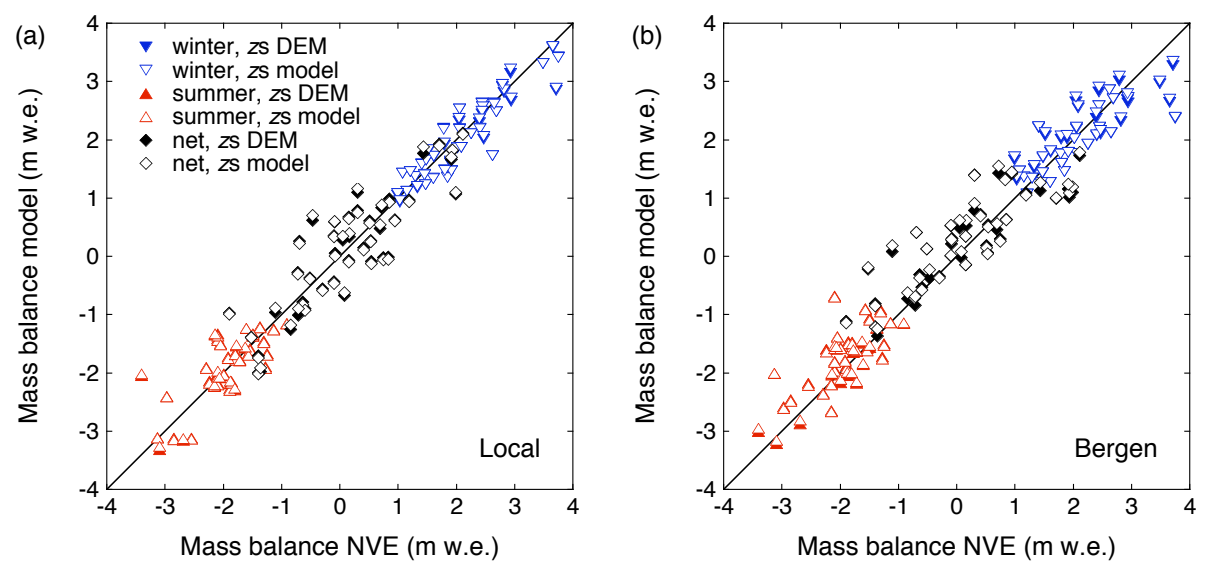

Fig. 6. Basin-averaged measured (NVE) and modelled winter, summer and net mass balance for Rembesdalsskåka for all 43 years in the period 1963-2005, using the input data from local stations and Bergen. Mass balances were calculated for a fixed topography $\left(z_{\mathrm{s}}\right.$ DEM) and the modelled topography from the 20th century run $\left(z_{\mathrm{s}}\right.$ model $)$.
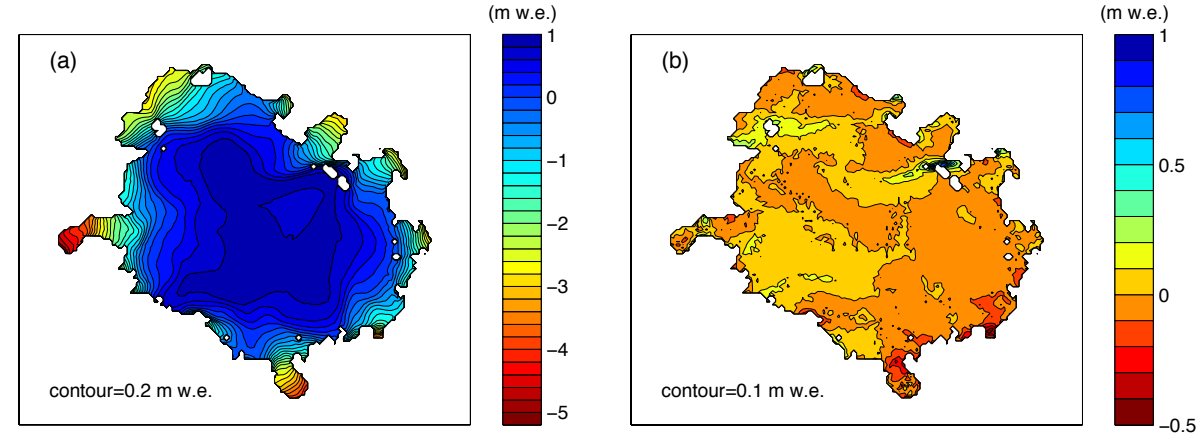

Fig. 7. (a) Mean and (b) altitudinal deviation of the net mass balance distribution for the period 1961-1990, modelled with local meteorological data. For each grid cell, the altitudinal deviation gives the mass balance deviation from the mean net mass balance for the corresponding $5 \mathrm{~m}$ altitude interval.

values modelled with local meteorological data over the period 1961-1990; the mass balance patterns are similar for other periods or input data, only the absolute values of the mass balance differ slightly.

The highest net mass balances are simulated for the upper ice cap with values around $+1 \mathrm{~m}$ w.e. (Fig. 7a). Mass balance values are slightly lower near the summit, a result of the prescribed decrease in precipitation at the highest altitudes. There is little spatial variation in the accumulation area compared to the outlet glaciers, where the slopes are larger. The altitudinal deviations of the net mass balance show that topographic effects generate considerable spatial variability in the annual net mass balance of the outlet glaciers (Fig. 7b). The imposed horizontal precipitation gradient affects the annual net mass balance by less than $\pm 0.1 \mathrm{~m}$ w.e.

\subsection{Mass balance sensitivity}

Changes in the surface mass balance corresponding to a $1 \mathrm{~K}$ change in air temperature $\left(C_{T}\right)$ and a $10 \%$ change in precipitation $\left(C_{P}\right)$ are often computed as a measure of a glacier's sensitivity to climate change. These static mass balance sensitivities $C_{T}$ and $C_{P}$ do not include ice dynamic effects and are defined as (Oerlemans, 2001):

$$
\begin{aligned}
C_{T} & =\frac{\mathrm{d} B_{\mathrm{n}}}{\mathrm{d} T_{\mathrm{a}}} \approx \frac{B_{\mathrm{n}}\left(T_{\mathrm{a}}+1\right)-B_{\mathrm{n}}\left(T_{\mathrm{a}}-1\right)}{\left(T_{\mathrm{a}}+1\right)-\left(T_{\mathrm{a}}-1\right)} \\
C_{P} & =\frac{\mathrm{d} B_{\mathrm{n}}}{\mathrm{d} P} \approx \frac{B_{\mathrm{n}}(P+10 \%)-B_{\mathrm{n}}(P-10 \%)}{(P+10 \%)-(P-10 \%)} .
\end{aligned}
$$

We calculated $C_{T}$ and $C_{P}$ for the present-day ice cap, using local input data for the period 1961-1990. Especially our value for $C_{T}$ is higher than found in other studies for Rembesdalsskåka (Table 4). The larger sensitivity found in this study possibly results from differences in model types. While we used a distributed energy balance approach, Rasmussen and Conway (2005) regressed measured mass balance with upper-air meteorological conditions and De Woul and Hock (2005) applied a degree-day model to nearby weather station data. The climate sensitivity calculated with the control climate is slightly lower than the values determined with local 


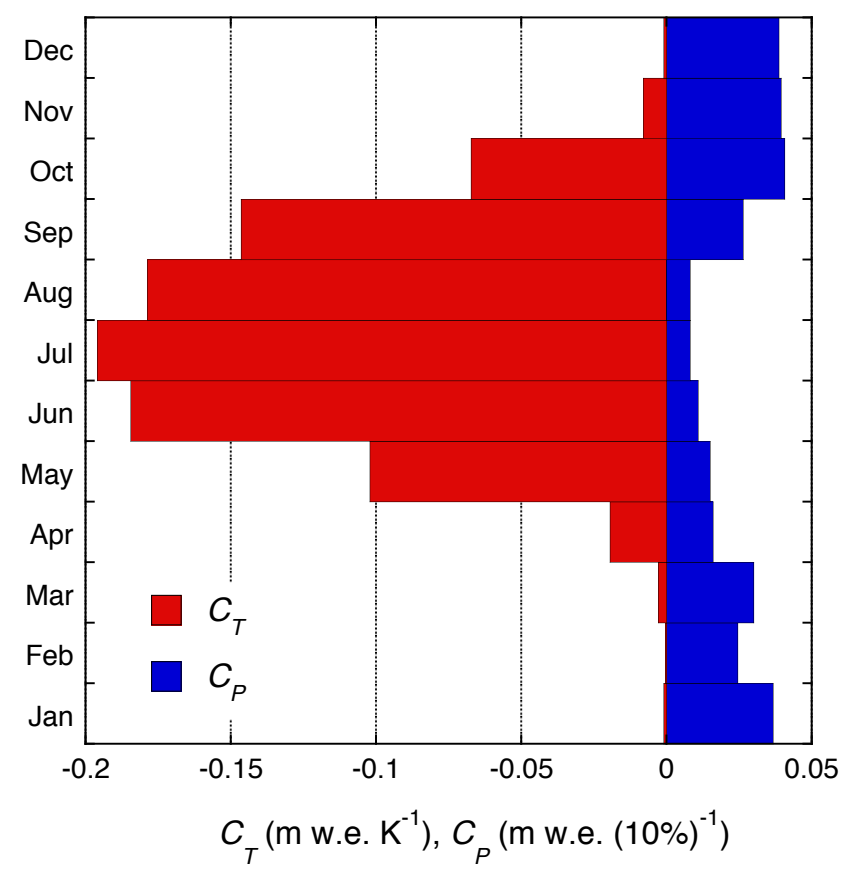

Fig. 8. Seasonal sensitivity characteristic of Hardangerjøkulen, showing the mass balance sensitivity to monthly perturbations in local air temperature and precipitation for the period 1961-1990. The monthly values were normalized to a period of 30 days.

data. These values suggest that at least a $30 \%$ increase in precipitation is needed to compensate the effect of a $1 \mathrm{~K}$ temperature increase.

The mass balance sensitivity for individual months is given by the seasonal sensitivity characteristic (SSC; Oerlemans and Reichert, 2000), where temperature or precipitation are only perturbed during one month at a time. We computed the SSC for Hardangerjøkulen, again using local input data for the period 1961-1990 (Fig. 8). A $1 \mathrm{~K}$ temperature change in the summer months has the largest effect on the net mass balance. These are the months with the largest surface energy fluxes and the transition from snow to ice albedos at the lower (June) to higher (August) altitudes and are therefore very sensitive to changes in the air temperature. In May and October, air temperatures are close to the threshold temperature for snow. A small shift in temperature then directly enhances or reduces snow accumulation, significantly affecting the winter balance. The mass balance sensitivity to precipitation perturbations is largest in winter, when mass balance changes are dictated by the amount of solid precipitation. The lower mass balance sensitivity to precipitation changes in February compared to the surrounding months is not resulting from the shorter length of this month; the sensitivities in Fig. 8 have been normalized to 30-day months. For the period 1961-1990, the precipitation in February is clearly smaller than for the other winter months.
Table 4. Static mass balance sensitivities to a $1 \mathrm{~K}$ change in air temperature $\left(C_{T}\right.$, in $\mathrm{mw}$.e. $\left.\mathrm{K}^{-1}\right)$ and a $10 \%$ change in precipitation $\left(C_{P}\right.$, in m w.e. $\left.(10 \%)^{-1}\right)$, determined from local meteorological data and the control climate for the period 1961-1990. For comparison, results from two earlier studies are also included.

\begin{tabular}{lcc}
\hline Reference & $C_{T}$ & $C_{P}$ \\
\hline Hardangerjøkulen & & \\
This study (local input data) & -0.94 & +0.30 \\
This study (control climate) & -0.85 & +0.29 \\
Rembesdalsskåka & & \\
This study (local input data) & -0.92 & +0.31 \\
This study (control climate) & -0.80 & +0.29 \\
Rasmussen and Conway (2005) & -0.64 & +0.22 \\
De Woul and Hock (2005) & -0.66 & +0.28 \\
\hline
\end{tabular}

\subsection{Hardangerjøkulen in the 20th century}

We now use the coupled model to simulate the ice cap evolution from 1905 to 2005 . With the coupled model, the surface mass balance not only varies due to changes in climate, but also reacts to changes in the surface topography and ice cap extent induced by ice cap's response to the mass balance history. When the coupled model is able to reproduce the length change records of Rembesdalsskåka and Midtdalsbreen and the observed surface topography and ice cap extent, we can be confident that the model is able to simulate a realistic ice cap evolution for a given future climate scenario.

Meteorological input data from Bergen are used until 1957, local meteorological data are used from 1958 onwards. Because there are no maps or outlines of Hardangerjøkulen available for the early 20th century, the ice cap geometry at the beginning of 1905 was taken as the 1904 ice cap modelled in the dynamic calibration. As described shortly in Sect. 3.1 and more detailed in Giesen (2009), Ch. 6, the calibration is based on the period 1600-2005, using a simpler mass balance model than in this study.

In 1905, the modelled margin of Hardangerjøkulen was located at an intermediate position between its maximum Little Ice Age extent and the present-day geometry (Fig. 9). The ice cap decreased in volume until 1917, followed by a number of positive mass balance years that let the ice cap volume increase almost back to its 1905 volume (Fig. 10) and geometry (Fig. 9). Rembesdalsskåka is known to have advanced about $50 \mathrm{~m}$ between 1919 and the late 1920s, building a distinct moraine before retreating again (Fægri, 1936). This advance is smaller than the model resolution $(100 \mathrm{~m})$ and is therefore not captured in the modelled length change record. The modelled frontal position of Rembesdalsskåka in 1928 corresponds well to the 1928 extent reported by Liest $\varnothing 1$ (1956). Midtdalsbreen is too large compared to the 1930 moraines identified by Andersen and Sollid (1971). After 

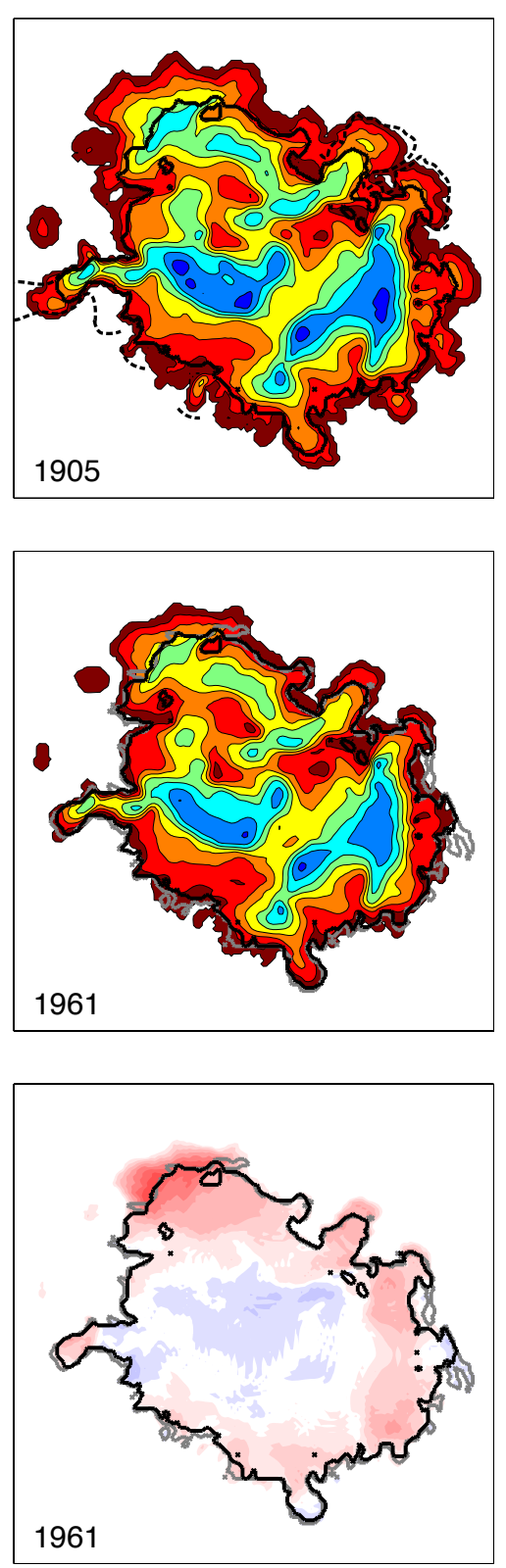
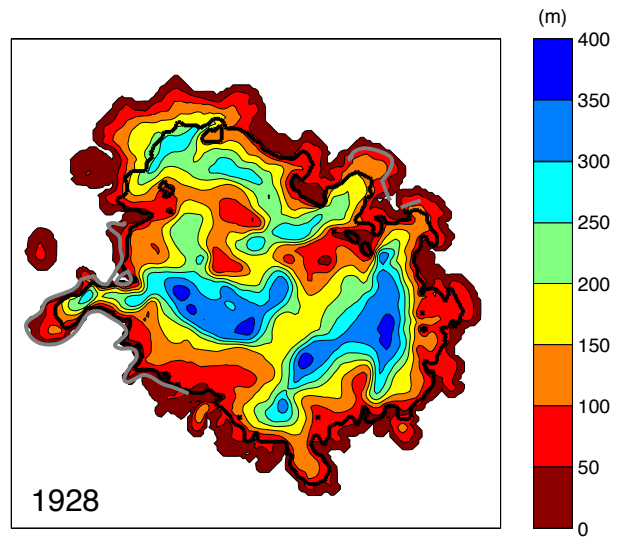

(m)

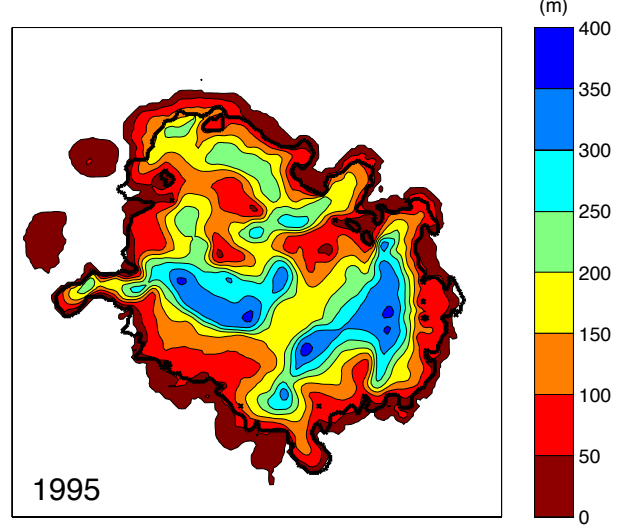

(m)

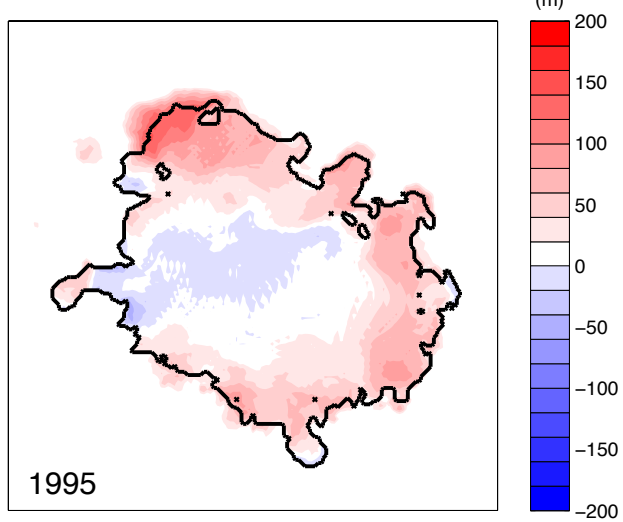

Fig. 9. Modelled ice thickness for 1905, 1928, 1961 and 1995. Contour lines are drawn for $50 \mathrm{~m}$ intervals. The lower two panels show the difference between the surface elevation modelled for 1961 and 1995 and the DEMs for these two years, with $20 \mathrm{~m}$ intervals. In all panels, the thick line represents the present-day ice cap margin. The dashed line in the panel for 1905 represents the LIA extent, also shown in Fig. 2. For 1928 and 1961, the contemporary ice margin is indicated by a grey line. For 1928, this is the 1928 margin around Rembesdalsskåka and the 1934 margin around Midtdalsbreen. References are given in the text.

this small advance in the 1920s, a period with highly negative annual mass balances led to fast volume decrease of Hardangerjøkulen until 1950 and an accelerated retreat of the outlet glaciers (Fig. 10). The net mass balance was less negative from 1949 onwards, reducing the speed of volume loss, while the outlet glaciers continued their retreat. Between 1928 and 1961 , the ice thickness substantially decreased over the entire ice cap and the ice cap margin retreated everywhere along the outline of Hardangerjøkulen (Fig. 9). The modelled ice cap extent in 1961 corresponds quite well to the mapped glacier outline for the south-western part of the ice cap; in the northern part the modelled ice cap is too large. The period between 1961 and 1995 is characterized by steadily increasing net mass balances, culminating in the anomalously positive mass balance years in the late 1980s and early 1990s. An advance in the late 1990s is modelled for Midtdalsbreen, but 

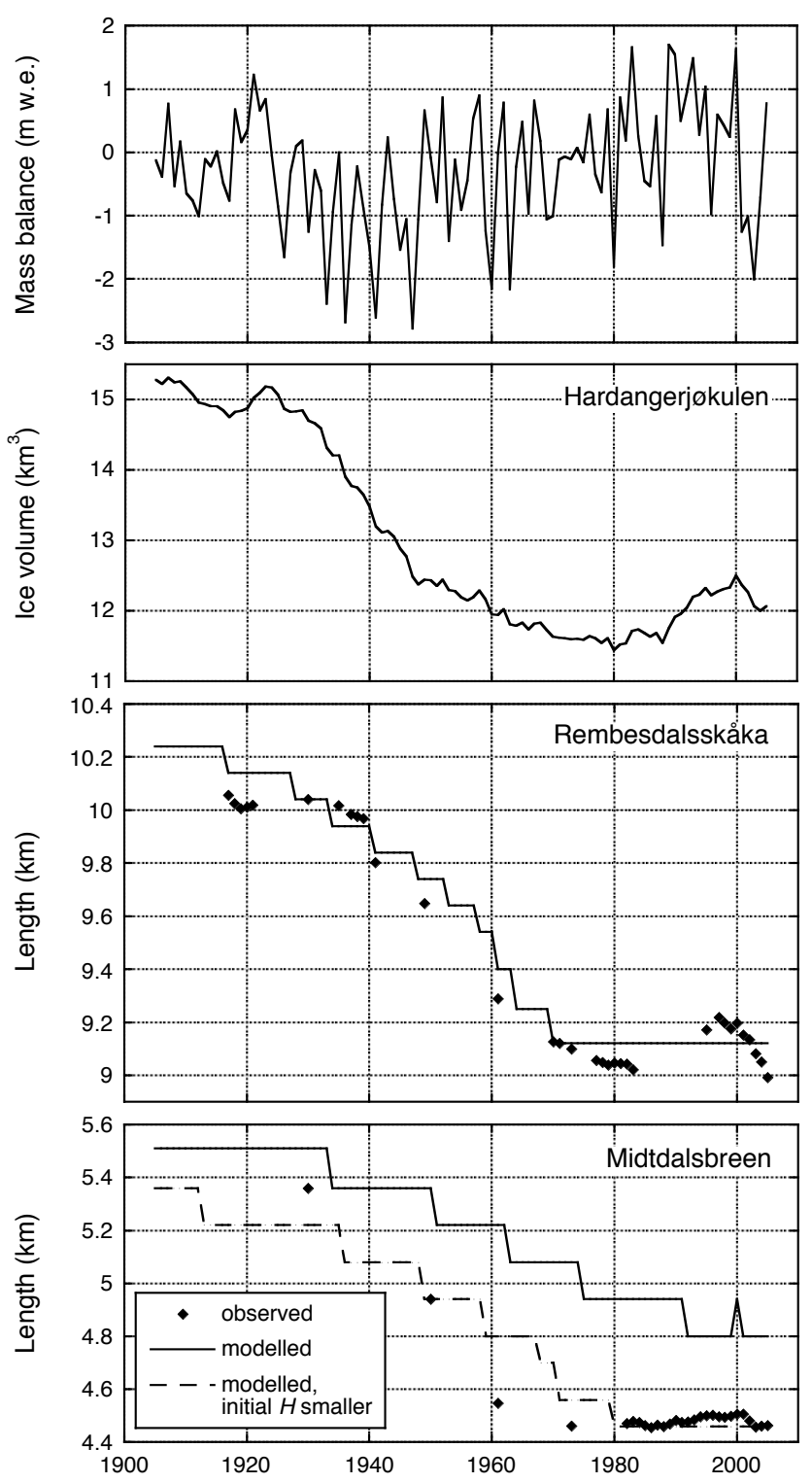

Fig. 10. Modelled net mass balance and ice volume for the entire ice cap and observed and simulated frontal variations at Rembesdalsskåka and Midtdalsbreen for the period 1905-2005. For Midtdalsbreen, an additional simulation starting from a smaller initial ice thickness is shown.

not for Rembesdalsskåka, where the measured advance was significantly larger (Fig. 10). The length change measurements are however conducted at a different location than the end of the flowline we used to determine the glacier length of Rembesdalsskåka. The model underestimates the length change of Midtdalsbreen through the entire 20th century. When we choose a smaller initial ice cap geometry to simulate the 20th century evolution of Midtdalsbreen, the length record is better reproduced. Hence, even for a century-long simulation, the initial conditions are important for the final result.
A comparison of the modelled surface topography for 1961 and 1995 with the DEMs for the same years, shows good correspondence in the ice cap interior and the southwestern outlet glaciers, while ice thickness is generally overestimated in the northern and eastern part of the ice cap (Fig. 9, lowest panels). The mean difference between modelled and measured surface elevations for glaciated grid cells is $+28.7 \mathrm{~m}$ for 1961 and $+33.3 \mathrm{~m}$ for 1995 , with standard deviations of 42.6 and $45.9 \mathrm{~m}$, respectively.

Overall, we find that the coupled model is well able to reproduce the observed variations of Hardangerjøkulen through the 20th century, measured surface elevations and the present-day ice cap margin. The model performance is somewhat less for the northern part of the ice cap, probably a result of the initial ice thickness or the precipitation distribution, which is more uncertain for this area.

\subsection{Hardangerjøkulen in the 21st century}

The effect of different climate scenarios on the modelled ice cap mass balance and volume and the length of Rembesdalsskåka and Midtdalsbreen is shown in Table 5. By our definition of the climate projection, the projected change in climate for 2071-2100 occurs in 2086. All absolute and relative changes are therefore given for the year 2086 with respect to a reference run with the unchanged control climate. The modelled volume and length evolution through the 21st century are shown in Fig. 11 for a selection of the investigated climate scenarios. Because we are interested in the response of the ice cap to different (simplified) climate scenarios and not in the variability induced by random climate fluctuations within individual scenarios, we did not add error bars.

When the climate is unchanged, i.e. when the control climate is prescribed, the net mass balance is slightly positive and Hardangerjøkulen retains its present-day geometry. For increasingly positive temperature anomalies, the ice volume decreases and Rembesdalsskåka and Midtdalsbreen retreat. For a temperature change of $+3^{\circ} \mathrm{C}$ over the period 1976 2086, distributed uniformly over the year, Hardangerjøkulen has almost completely disappeared by the year 2100 . It should be noted that the large jumps in the lengths of Rembesdalsskåka and Midtdalsbreen prior to their disappearance occur because the ice disappearing last from the basins is not situated at the beginning of the flowline. The glacier length is nevertheless defined as the distance from the beginning of the flowline to the lowest point with ice.

Climate warming mainly affects the summer mass balance, but the winter balance also significantly decreases. A $10 \%$ precipitation increase along with the $3^{\circ} \mathrm{C}$ temperature increase has only a small effect on the projected volume and length changes. For a 50\% precipitation increase, the ice cap disappears more slowly, but the effect of the temperature increase is not compensated. Even for a doubling of the precipitation $(\Delta P=+100 \%)$, which could compensate a 
$3{ }^{\circ} \mathrm{C}$ warming according to the computed static mass balance sensitivities (Sect. 5.5), a significant reduction of Hardangerjøkulen's ice volume is projected for 2100. Apparently, nonlinear effects associated with the larger temperature change than the $1{ }^{\circ} \mathrm{C}$ used to compute the mass balance sensitivities and the transient nature of the climate projections lead to more negative surface mass balances.

Adding a seasonal cycle to the linearly changing air temperature and precipitation does not lead to a notably different response of the ice cap when the maximum change occurs in autumn (15 October) (Table 5). However, when the maximum change occurs in winter (15 January), the winter balance remains more positive and the summer and net balance less negative compared to a constant annual change, resulting in a slower decrease in ice volume and retreat of the outlet glaciers. Hence, the timing of the maximum change in temperature and precipitation does affect the mass balance and consequently the response of the ice cap. The mass balance on Hardangerjøkulen is most sensitive to temperature changes in mid-summer and precipitation changes in lateautumn and early winter (Sect. 5.5). When the maximum temperature change occurs in winter, modelled temperatures are still far too low to affect the snow accumulation or induce melt (Fig. 4). On the other hand, the smaller temperature increase from late spring to early autumn with respect to a constant annual change, leads to a higher winter balance and less summer ablation. Additional precipitation in winter further enhances this effect. For a maximum change in autumn, the mass balance is similar to the projection without a seasonal cycle because opposite changes occur in spring and autumn, when the sensitivity to temperature and precipitation changes is similar.

An increase in the wind speed, simulated by a $10 \%$ increase in the turbulent exchange coefficient together with the $3{ }^{\circ} \mathrm{C}$ temperature increase, only slightly alters the results from the projection with $\Delta T=+3^{\circ} \mathrm{C}$ (Table 5). A similar result is obtained for a cloud fraction increase of +0.05 , both experiments also follow trajectories very close to the $\Delta T=+3{ }^{\circ} \mathrm{C}$ trajectory. Apparently, the effect of the temperature increase on the incoming longwave radiation and the turbulent fluxes is much larger than changes induced by an increase in cloudiness or wind speed.

For one of the most probable scenarios according to the RegClim results $\left(\Delta T=+3{ }^{\circ} \mathrm{C}\right.$ and $\left.\Delta P=+10 \%\right)$, we discuss the modelled future changes in more detail. In the very near future, by 2010 , the equilibrium-line altitude (ELA) is expected to be situated around $1740 \mathrm{~m}$ a.s.l. and only $35 \%$ of the total ice cap is located above the ELA (Fig. 12). However, the 2010 ice cap (Fig. 13) is very similar to the ice cap modelled for 1995 (Fig. 9) and 2005, because the ice volume only just started to decrease after reaching a maximum in the year 2000 (Fig. 10). Between 2010 and 2040, the net mass balance becomes negative at all altitudes (Fig. 12a), implying that the entire ice cap is destined to disappear, even without further increased future warming. A temperature
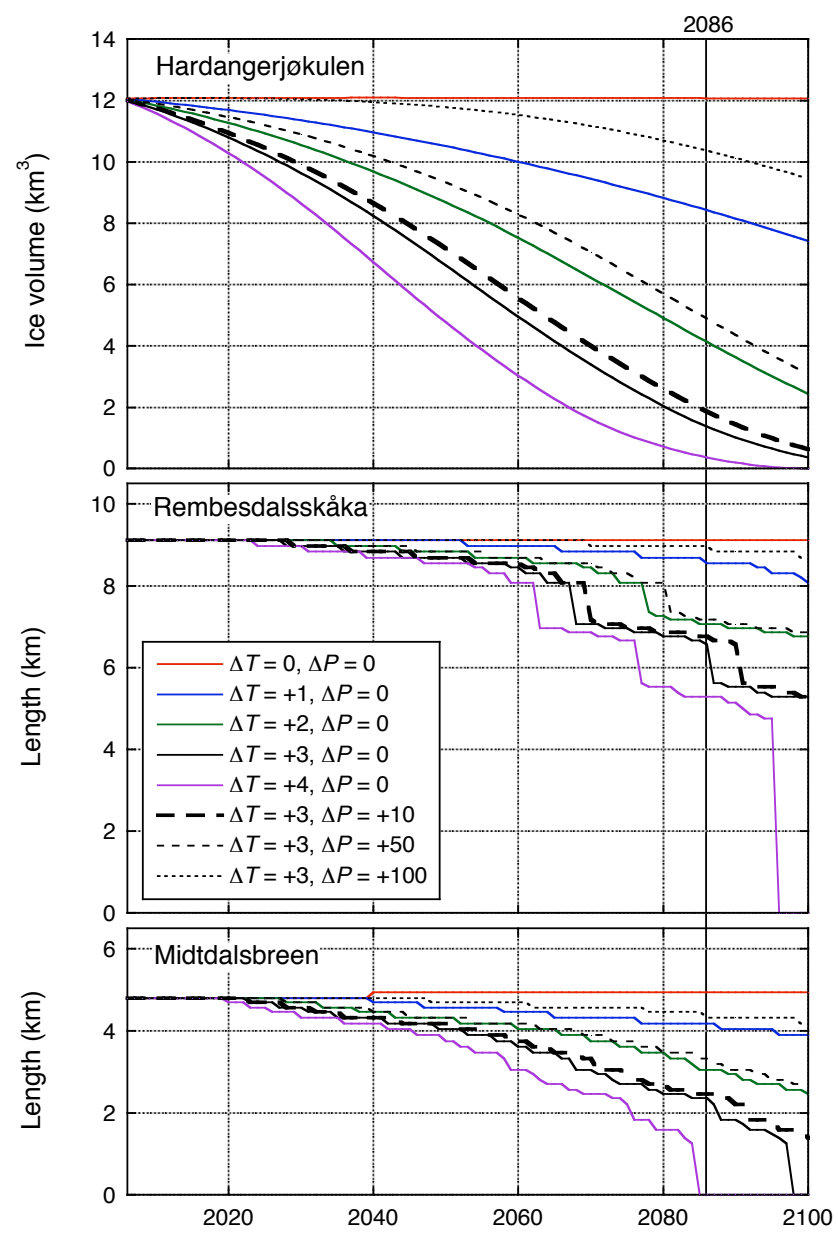

Fig. 11. Ice cap volume and length change for Rembesdalsskåka and Midtdalsbreen from 1905 to 2100 for different climate scenarios applied from 2006 onwards. The imposed temperature $(\Delta T$ in $\left.{ }^{\circ} \mathrm{C}\right)$ and precipitation $(\Delta P$ in $\%)$ changes are constant through the year.

change exceeding $+1^{\circ} \mathrm{C}$ already positions the ELA above the ice cap; in this simulation this occurs around the year 2015. The largest mass balance changes are simulated at the higher altitudes, where the albedo changes most. In 2040, the outlet glaciers have retreated from the present-day margin and the ice thickness in the interior has approximately decreased by $50 \mathrm{~m}$. A significant retreat occurs between 2040 and 2070, the ice cap plateau splits up into separate outlet glaciers and the ice thickness decreases considerably (Fig. 13). Because the present-day ice is relatively thin at the high bedrock ridges ( $<100 \mathrm{~m}$, Fig. 9), it has completely melted away by 2070 , while ice still remains at the lower altitudes where the ice is thicker. By 2100 , almost all ice has disappeared, thin ice only remains in the basins where the present-day ice is thickest. 
Table 5. Effect of different changes in air temperature $(\Delta T)$ and precipitation $(\Delta P)$ on the modelled winter $\left(B_{\mathrm{W}}\right)$, summer $\left(B_{\mathrm{S}}\right)$ and net $\left(B_{\mathrm{n}}\right)$ surface mass balance and ice volume $\left(V_{\text {ice }}\right)$ of Hardangerjøkulen and the length of Rembesdalsskåka $\left(L_{\text {Remb }}\right)$ and Midtdalsbreen $\left(L_{\text {Midt }}\right)$ in the year 2086. The climate projections are prescribed as an annual and as a seasonally varying change, with the maximum on either 15 October or 15 January. Results from climate projections with a higher wind speed $\left(K_{\mathrm{b}} \times 1.1\right)$ and increased cloudiness $(n+0.05)$ are also included. All changes $(\Delta)$ are given with respect to the reference run with the control climate for 1961-1990. The surface mass balance is the total surface mass balance over the modelled ice cap.

\begin{tabular}{|c|c|c|c|c|c|c|c|c|}
\hline & $\begin{array}{r}\Delta T \\
\left({ }^{\circ} \mathrm{C}\right)\end{array}$ & $\begin{array}{l}\Delta P \\
(\%)\end{array}$ & $\begin{array}{c}B_{\mathrm{W}} \\
\text { (m w.e.) }\end{array}$ & $\begin{array}{c}B_{\mathrm{S}} \\
\text { (m w.e.) }\end{array}$ & $\begin{array}{c}B_{\mathrm{n}} \\
\text { (mw.e.) }\end{array}$ & $\begin{array}{c}V_{\text {ice }} \\
\left(\mathrm{km}^{3}\right)\end{array}$ & $\begin{array}{r}L_{\text {Remb }} \\
(\mathrm{km})\end{array}$ & $\begin{array}{r}L_{\text {Midt }} \\
(\mathrm{km})\end{array}$ \\
\hline \multirow[t]{2}{*}{ Reference } & 0 & 0 & +2.03 & -1.95 & +0.08 & 12.1 & 9.1 & 4.9 \\
\hline & & & $\begin{array}{c}\Delta B_{\mathrm{W}} \\
\text { (m w.e.) }\end{array}$ & $\begin{array}{c}\Delta B_{\mathrm{S}} \\
\text { (m w.e.) }\end{array}$ & $\begin{array}{c}\Delta B_{\mathrm{n}} \\
\text { (m w.e.) }\end{array}$ & $\begin{array}{c}\Delta V_{\text {ice }} \\
(\%)\end{array}$ & $\begin{array}{r}\Delta L_{\mathrm{Remb}} \\
(\%)\end{array}$ & $\begin{array}{r}\Delta L_{\mathrm{Midt}} \\
(\%)\end{array}$ \\
\hline Annual & +1 & 0 & -0.12 & -0.83 & -0.96 & -31 & -5 & -14 \\
\hline Annual & +2 & 0 & -0.45 & -2.30 & -2.75 & -64 & -22 & -37 \\
\hline Annual & +3 & 0 & -0.96 & -3.53 & -4.50 & -88 & -27 & -51 \\
\hline Annual & +4 & 0 & -1.52 & -4.76 & -6.28 & -97 & -42 & -100 \\
\hline Annual & +3 & +10 & -0.71 & -3.39 & -4.10 & -84 & -25 & -49 \\
\hline Annual & +3 & +50 & +0.32 & -2.93 & -2.61 & -60 & -21 & -23 \\
\hline Annual & +3 & +100 & +1.60 & -2.36 & -0.76 & -14 & -2 & -12 \\
\hline Seasonal, max. 15 Oct & +3 & 0 & -0.98 & -3.56 & -4.54 & -89 & -27 & -55 \\
\hline Seasonal, max. 15 Oct & +3 & +10 & -0.68 & -3.41 & -4.08 & -84 & -25 & -49 \\
\hline Seasonal, max. 15 Jan & +3 & 0 & -0.79 & -3.02 & -3.81 & -81 & -25 & -47 \\
\hline Seasonal, max. 15 Jan & +3 & +10 & -0.33 & -2.79 & -3.12 & -70 & -23 & -39 \\
\hline Annual, $K_{\mathrm{b}} \times 1.1$ & +3 & 0 & -1.03 & -3.82 & -4.85 & -91 & -38 & -63 \\
\hline Annual, $n+0.05$ & +3 & 0 & -1.01 & -4.18 & -5.20 & -89 & -28 & -55 \\
\hline
\end{tabular}
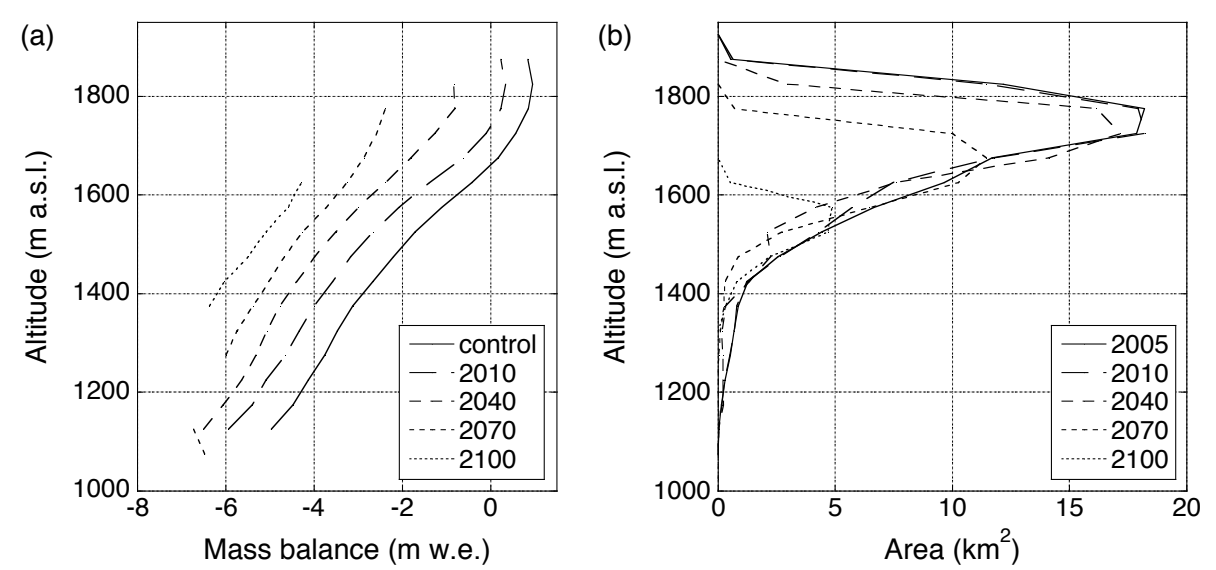

Fig. 12. Modelled (a) net mass balance profile and (b) area distribution for 2010, 2040, 2070 and 2100, for the climate projection with $\Delta T=+3{ }^{\circ} \mathrm{C}$ and $\Delta P=+10 \%$. The mass balance profile for the control climate and the area distribution at the end of 2005 are shown for reference.

\subsection{Feedback processes}

The role of feedback processes in the response of Hardangerjøkulen was investigated by performing additional model simulations for $\Delta T=+3{ }^{\circ} \mathrm{C}$ and $\Delta P=+10 \%$ and excluding one process at a time.

As explained in Sect. 3.3, we anticipated the observed maximum in the vertical winter balance profile to be determined by the plateau shape and less by the absolute elevation of the summit. We therefore allowed the maximum in the vertical precipitation profile to change along with the ice cap summit elevation. The altitude above which the turbulent exchange coefficient is prescribed to increase, also depends on the summit elevation. To determine the effect of these assumptions on the 21st century ice cap projections, the model simulations for $\Delta T=+3{ }^{\circ} \mathrm{C}$ and $\Delta P=+10 \%$ were repeated without adapting these two prescribed profiles. 

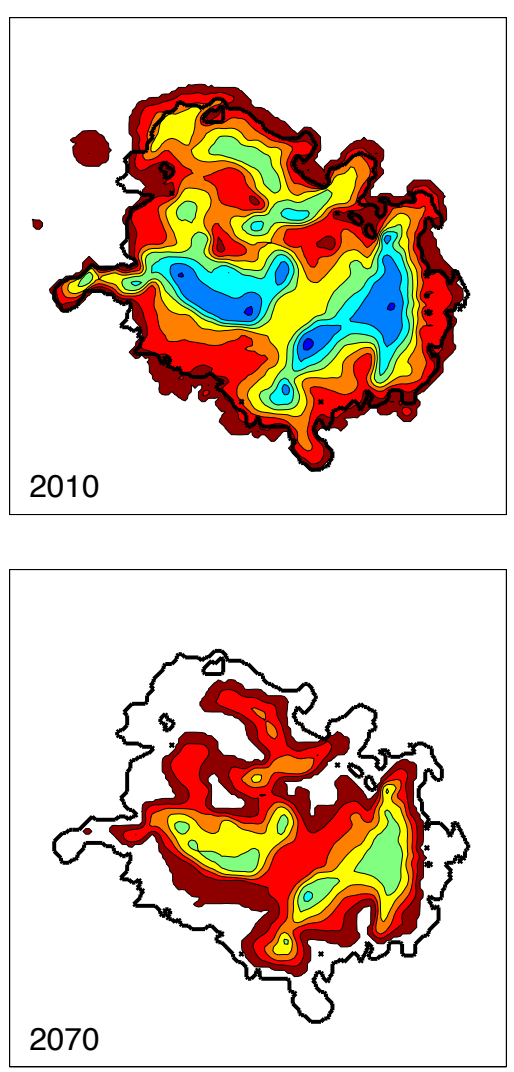

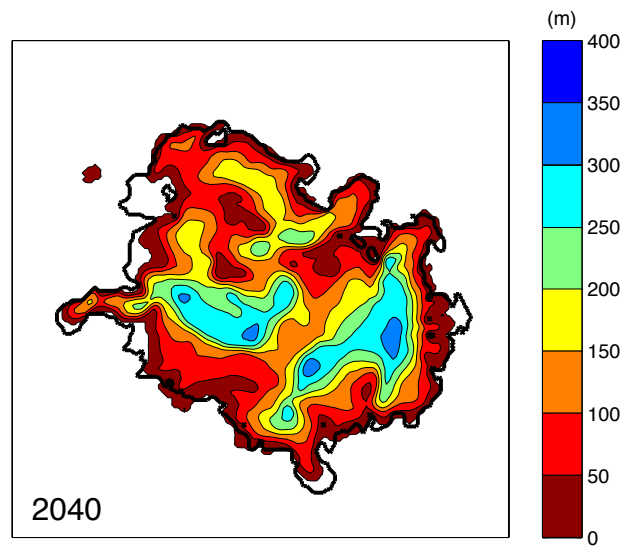

(m)

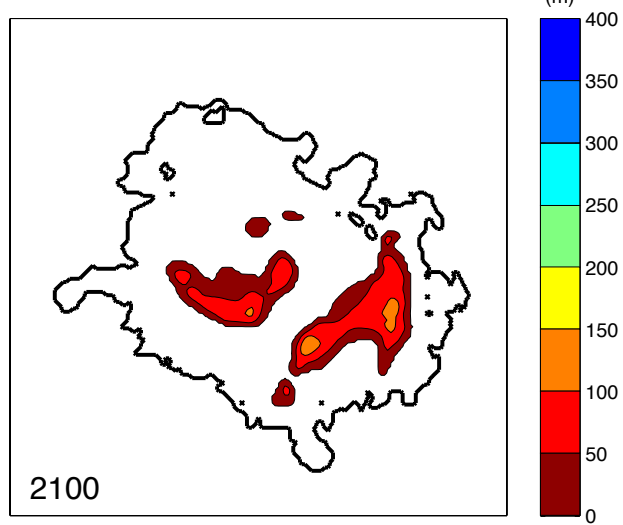

Fig. 13. Modelled ice thickness for $2010,2040,2070$ and 2100 , for the climate projection with $\Delta T=+3{ }^{\circ} \mathrm{C}$ and $\Delta P=+10 \%$. Contour lines are drawn every $50 \mathrm{~m}$. The thick line indicates the present-day ice cap margin.

Figure 14 shows that the the modelled ice cap response is only marginally affected.

To determine the effect of the mass balance-altitude feedback, the mass balance distribution was computed on the 2005 topography for all years. In the first years, the ice volume decrease is only slightly smaller when the mass balancealtitude feedback is excluded (Fig. 14), because the surface topography is still similar. By the year 2100 , the ice volume difference has increased to almost $2 \mathrm{~km}^{3}$ or $15 \%$ of the initial ice volume (2006).

Subsequently, we completely turned off ice flow to assess to what extent volume changes are determined by the local surface mass balance. Because the ice is no longer transported from high to low mass balance areas, thinning increases at the lower altitudes, while the change in ice thickness is reduced at the upper altitudes. As a result, the ice volume decreases more slowly than in the original simulation and attains almost exactly the same value in 2100 as in the simulation without mass balance-altitude feedback.

These experiments show that including ice flow and the mass balance-altitude feedback in a realistic way significantly speeds up the ice volume decrease. Nevertheless, in this case the mass balance changes projected for the future are so large that Hardangerjøkulen still rapidly disappears when these processes are not included.

\section{Conclusions and discussion}

A spatially distributed mass balance model was coupled to a vertically-integrated ice-flow model based on the shallow-ice approximation, to simulate the response of Hardangerjøkulen to projected climate change in the 21 st century. By using a mass balance model including physical parameterizations of the surface energy fluxes, projected changes in the meteorological variables could directly be incorporated in the model. The interactive coupling of the mass balance with an twodimensional ice-flow model ensured that feedback processes were included. The model was first validated with a simulation through the 20th century and was found to reproduce the evolution of Hardangerjøkulen as observed from changes in outlet glacier lengths and the surface topography.

For the projected $3{ }^{\circ} \mathrm{C}$ warming, the model simulation indicated that Hardangerjøkulen will almost entirely disappear before the end of the 21 st century. The probable $10 \%$ increase in precipitation only slightly changed the modelled 


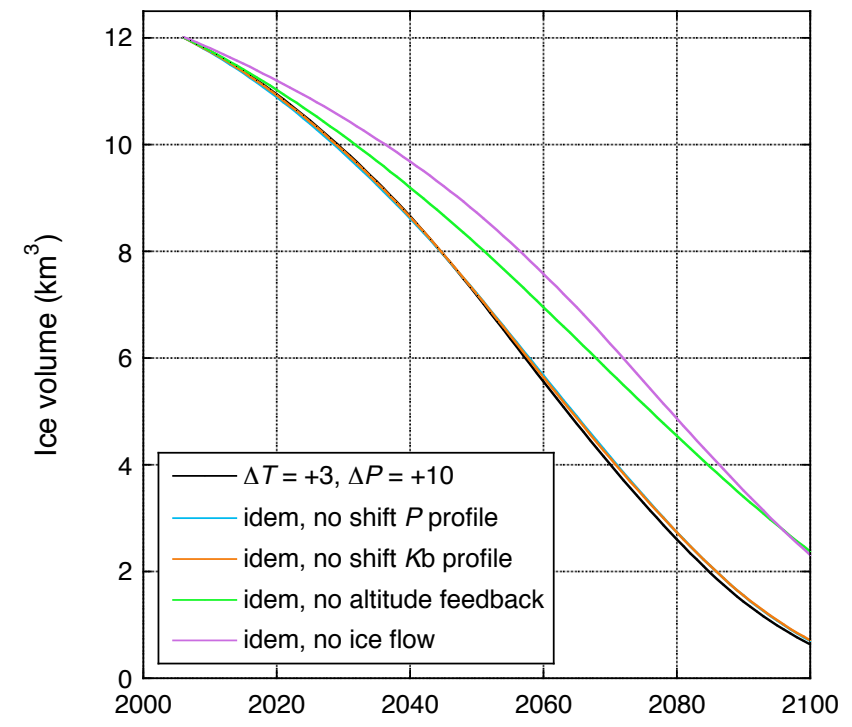

Fig. 14. Modelled ice cap volume from 2006 to 2100 for the climate projection with $\Delta T=+3{ }^{\circ} \mathrm{C}$ and $\Delta P=+10 \%$, shown together with simulations without shifting the vertical precipitation and $K_{\mathrm{b}}$ profiles, without the mass balance-altitude feedback and without ice flow.

response; even a $100 \%$ precipitation increase could not fully compensate the effect of the temperature change. When the largest changes in temperature and precipitation were prescribed in winter, similar to the projections, the ice cap disappeared slower. However, none of the probable changes in the other meteorological variables had such a large effect as a $3{ }^{\circ} \mathrm{C}$ warming.

Although we used a physically based model, there are still many factors adding uncertainty to the results. First of all, the future climate was modelled in a simple way to allow for an elementary comparison of the ice cap response over a range of future climates. The interannual variability in the present-day climate of southern Norway is large, but we prescribed the same annual cycle for every year. Moreover, the projected climate change was assumed to be constant or seasonally varying, while changes will most likely not be the same for different weather types. Secondly, the mass balance model contains several parameterizations which may be different for the future climate and ice cap. One example is the ice albedo, which was assumed to be constant in space and time. In a warmer climate with less snowfall and a larger ablation area, more dust may accumulate on the ice surface, decreasing the albedo. A systematic lowering of the ice albedo has already been observed on Morteratschgletscher in Switzerland (Oerlemans et al., 2009). Still, lowering the ice albedo from 0.35 to 0.20 in the model simulation with $\Delta T=+3{ }^{\circ} \mathrm{C}$ and $\Delta P=+10 \%$, only leads to a $5 \%$ larger volume decrease. The precipitation distribution and the snowpack structure were also simulated in a simple way and may not be correct for a warmer climate and a different ice cap topography. A high-resolution atmospheric model and a sophisticated snowpack model are needed to improve the model in this respect, which is outside the scope of this study. Finally, increased meltwater production at the surface may enhance basal sliding and change the ice dynamics of Hardangerjøkulen. We however expect that the warm, present-day ice cap already has an efficient drainage system and that this effect will therefore be small.

Another source of uncertainty is associated with the boundary conditions, in particular the bedrock topography. For considerable parts of the ice cap, the bedrock topography was derived from sparse ice thickness measurements and the uncertainty may be as large as $50 \mathrm{~m}$. Since the mismatch between the modelled and observed surface topography in 1995 could result from an incorrect bedrock topography, we adjusted the bedrock topography by subtracting half of the difference between the modelled surface topography for 1995 and the 1995 DEM, as shown in Fig. 9. To avoid large jumps and inconsistencies at the ice cap margin, the bedrock topography for grid cells not solely surrounded by glaciated cells was not adapted and for all other glaciated grid cells, we used the mean value over nine grid cells with the evaluated grid cell in the center. Elevation differences between the new and the original bedrock topography range between -69 and $+23 \mathrm{~m}$, well representing the estimated uncertainty in the bedrock topography. An additional simulation from 1905 to 2100 was performed with this new bedrock topography, using the same initial surface topography as before and the $\Delta T=+3{ }^{\circ} \mathrm{C}$ and $\Delta P=+10 \%$ future scenario. The initial volume is almost $1 \mathrm{~km}^{3}$ larger because the new bedrock topography is generally lower than the original. The ice volume difference reduces during the 20th century, becomes negative in 1986 and by the year 2100 , the ice volume modelled with the new bed topography is $0.4 \mathrm{~km}^{3}$ smaller than in the original simulation. The evolution of the ice cap geometry during the 20th and 21st century, modelled with the new bedrock topography, is also hardly discernible from the original results. As the ice volume difference does not exceed $\pm 1 \mathrm{~km}^{3}$ during the entire simulation and geometry changes are small, this experiment confirms that uncertainties in the bedrock topography do not substantially affect our results.

By using a coupled model where the terms in the surface energy and mass balance are computed individually, the effect of climate change on the mass balance and geometry of Hardangerjøkulen was included in a realistic way. We have demonstrated that the largest uncertainties in the model results can be ascribed to the large range in climate scenarios and not to the model design or the boundary conditions. We can conclude that, provided that a $3{ }^{\circ} \mathrm{C}$ warming indeed occurs in the 21 st century and the precipitation increase is modest, Hardangerjøkulen is bound to disappear within the next 100 years.

The other maritime glaciers and ice caps in southern Norway have similar characteristics as Hardangerjøkulen and will probably also rapidly lose volume in the 21 st century. 
A fast disappearance in a warmer climate has been projected for Nigardsbreen, an outlet glacier from the ice cap Jostedalsbreen, $130 \mathrm{~km}$ north of Hardangerjøkulen (Oerlemans, 1997). Although he uses a simple mass balance representation and a flowline model, the results are similar. Only a small warming rate is needed for a significant decrease in ice volume, a simultaneous increase in precipitation only delays the glacier retreat. The more continental glaciers further inland have a more regular hypsometry and are situated at higher altitudes. These glaciers are less sensitive to climate change and have a better chance to survive the 21st century, although largely reduced in size. Still, reconstructions of the Holocene glacier extent in southern Norway suggest that glaciers were absent in all glacierized regions during one or more periods in the early-/mid-Holocene (Nesje et al., 2008), while air temperatures were probably lower than the temperatures projected for the end of the 21st century (Bjune et al., 2005). Applying the coupled model to a number of wellstudied glaciers in different regions could give a more definitive answer on the future of the glaciers in southern Norway.

Acknowledgements. We gratefully acknowledge Jojanneke van den Berg for providing the ice-flow model code and Kjetil Melvold for providing ice thickness measurements and computing the ice thickness distribution for the entire ice cap. We thank NVE, in particular Hallgeir Elvehøy, for providing the mass balance and length change measurements. The Norwegian Meteorological Institute is acknowledged for access to and use of their meteorological database eKlima. Faron Anslow and two anonymous referees are thanked for their constructive comments that helped to clarify the paper.

Edited by: I. M. Howat

\section{References}

Aðalgeirsdottir, G., Jóhannesson, T., Björnsson, H., Pálsson, F., and Sigurðsson, O.: Response of Hofjökull and southern Vatnajökull, Iceland, to climate change, J. Geophys. Res., 111, F03001, doi: 10.1029/2005JF000388, 2006.

Andersen, J. L. and Sollid, J. L.: Glacial chronology and glacial geomorphology in the marginal zones of the glaciers, Midtdalsbreen and Nigardsbreen, south Norway, Norsk Geogr. Tidssk., $25,1-38,1971$.

Andreassen, L. M. and Elvehøy, H.: Volume change - Hardangerjøkulen, in: Glaciological investigations in Norway in 2000, edited by: Kjøllmoen, B., NVE Report No 2, Norwegian Water Resources and Energy Directorate, Oslo, 101-102, 2001.

Andreassen, L. M., Elvehøy, H., Kjøllmoen, B., Engeset, R. V., and Haakensen, N.: Glacier mass-balance and length variation in Norway, Ann. Glaciol., 42, 317-325, 2005.

Arnold, N. S., Rees, W. G., Hodson, A. J., and Kohler, J.: Topographic controls on the surface energy balance of a high Arctic valley glacier, J. Geophys. Res., 111, F02011, doi:10.1029/ 2005JF000426, 2006.
Bahr, D. B., Dyurgerov, M., and Meier, M. F.: Sea-level rise from glaciers and ice caps: A lower bound, Geophys. Res. Lett., 36, L03501, doi:10.1029/2008GL036309, 2009.

Bjune, A. E., Bakke, J., Nesje, A., and Birks, H. J. B.: Holocene mean July temperature and winter precipitation in western Norway inferred from palynological and glaciological lake-sediment proxies, The Holocene, 15, 177-189, 2005.

Budd, W. F., Keage, P. L., and Blundy, N. A.: Empirical studies of ice sliding, J. Glaciol., 23, 157-170, 1979.

De Woul, M. and Hock, R.: Static mass-balance sensitivity of Arctic glaciers and ice caps using a degree-day approach, Ann. Glaciol., 42, 217-224, 2005.

Dozier, J. and Frew, J.: Rapid calculation of terrain parameters for radiation modeling from digital elevation data, IEEE T. Geosci. Remote, 28, 963-969, 1990.

Elvehøy, H., Kohler, J., Engeset, R., and Andreassen, L. M.: Jøkullaup fra Demmevatn, NVE Report No 17, Norwegian Water Resources and Energy Directorate, Oslo, 36 pp., 1997.

Fægri, K.: Forandringer ved norske breer 1934-35, Bergen Museums Årbok 1935, Naturvidenskapelig rekke Nr. 6, Bergen, Norway, 10 pp., 1936.

Farinotti, D., Huss, M., Bauder, A., Funk, M., and Truffer, M.: A method to estimate the ice volume and ice-thickness distribution of alpine glaciers, J. Glaciol., 55, 422-430, 2009.

Flowers, G. E., Marshall, S. J., Björnsson, H., and Clarke, G. K. C.: Sensitivity of Vatnajökull ice cap hydrology and dynamics to climate warming over the next 2 centuries, J. Geophys. Res., 110, F02011, doi:10.1029/2004JF000200, 2005.

Gerbaux, M., Genthon, C., Etchevers, P., Vincent, C., and Dedieu, J. P.: Surface mass balance of glaciers in the French Alps: distributed modeling and sensitivity to climate change, J. Glaciol., 51, 561-572, 2005.

Giesen, R. H.: Surface energy and mass balance at Hardangerjøkulen, southern Norway, Master's thesis, Institute for Marine and Atmospheric research Utrecht, Utrecht University, 2004.

Giesen, R. H.: The ice cap Hardangerjøkulen in the past, present and future climate, Ph.D. thesis, Institute for Marine and Atmospheric research Utrecht, available at: http://igitur-archive. library.uu.nl/dissertations/2009-1104-200130/UUindex.html, Utrecht University, The Netherlands, 2009.

Giesen, R. H., Van den Broeke, M. R., Oerlemans, J., and Andreassen, L. M.: The surface energy balance in the ablation zone of Midtdalsbreen, a glacier in southern Norway: Interannual variability and the effect of clouds, J. Geophys. Res., 113, D21111, doi:10.1029/2008JD010390, 2008.

Giesen, R. H., Andreassen, L. M., van den Broeke, M. R., and Oerlemans, J.: Comparison of the meteorology and surface energy balance at Storbreen and Midtdalsbreen, two glaciers in southern Norway, The Cryosphere, 3, 57-74, doi:10.5194/tc-3-57-2009, 2009.

Gordon, C., Cooper, C., Senior, C. A., Banks, H., Gregory, J. M., Johns, T. C., Mitchell, J. F. B., and Wood, R. A.: The simulation of SST, sea ice extents and ocean heat transports in a version of the Hadley Centre coupled model without flux adjustments, Clim. Dynam., 16, 147-168, 2000.

Green, F. H. W. and Harding, R. J.: The altitudinal gradients of air temperature in southern Norway, Geogr. Ann. A, 62, 29-36, 1980. 
Greuell, W. and Oerlemans, J.: Sensitivity studies with a mass balance model including temperature profile calculations inside the glacier, Z. Gletscherkd. Glazialgeol., 22, 101-124, 1986.

Greuell, W., Knap, W. H., and Smeets, P. C.: Elevational changes in meteorological variables along a midlatitude glacier during summer, J. Geophys. Res., 102, D22, 1997.

Hanssen-Bauer, I., Førland, E. J., Haugen, J. E., and Tveito, O. E.: Temperature and precipitation scenarios for Norway: comparison of results from dynamical and empirical downscaling, Clim. Res., 25, 15-27, 2003.

Hutter, K.: Theoretical glaciology : material science of ice and the mechanics of glaciers and ice sheets, Reidel, Dordrecht, The Netherlands, 1983.

Huybrechts, P.: The Antarctic ice sheet and environmental change: a three-dimensional modelling study, Reports on polar research, 99, 241 pp., 1992.

IPCC: Climate Change 2007: The Physical Science Basis, Contribution of Working Group I to the Fourth Assessment Report of the Intergovernmental Panel on Climate Change, edited by: Solomon, S., Qin, D., Manning, M., Chen, Z., Marquis, M., Averyt, K. B., Tignor, M., and Miller, H. L., Cambridge University Press, Cambridge, UK and New York, NY, USA, 2007.

Iqbal, M.: An introduction to solar radiation, Academic Press, New York, 1983.

Kjøllmoen, B., Andreassen, L. M., Engeset, R. V., Elvehøy, H., Jackson, M., and Giesen, R. H.: Glaciological investigations in Norway in 2005, NVE Report No 2, Norwegian Water Resources and Energy Directorate, Oslo, 91 pp., 2006.

Kjøllmoen, B., Andreassen, L. M., Elvehøy, H., Jackson, M., Giesen, R. H., and Winkler, S.: Glaciological investigations in Norway in 2007, NVE Report No 3, Norwegian Water Resources and Energy Directorate, Oslo, 91 pp., 2008.

Klok, E. J. and Oerlemans, J.: Model study of the spatial distribution of the energy and mass balance of Morteratschgletscher, Switzerland, J. Glaciol., 48, 505-518, 2002.

Klok, E. J., Greuell, W., and Oerlemans, J.: Temporal and spatial variation of the surface albedo of Morteratschgletscher, Switzerland, as derived from 12 Landsat images, J. Glaciol., 49, 491502, 2003.

Konzelmann, T., van de Wal, R. S. W., Greuell, W., Bintanja, R., Henneken, E. A. C., and Abe-Ouchi, A.: Parameterization of global and longwave incoming radiation for the Greenland Ice Sheet, Global Planet. Change, 9, 143-164, 1994.

Laumann, T.: Sn $\varnothing$, firn, is - en unders $\varnothing$ kelse på Hardangerjøkulen, Master's thesis, University of Oslo, 1972.

Le Meur, E., Gerbaux, M., Schäfer, M., and Vincent, C.: Disappearance of an Alpine glacier over the 21 st Century simulated from modeling its future surface mass balance, Earth Planet. Sc. Lett., 261, 367-374, 2007.

Leysinger Vieli, G. J.-M. C. and Gudmundsson, G. H.: On estimating length fluctuations of glaciers caused by changes in climatic forcing, J. Geophys. Res., 109, F01007, doi:10.1029/ 2003JF000027, 2004.

Liestøl, O.: Glacier dammed lakes in Norway, Norsk Geogr. Tidssk., 15, 122-149, 1956.

Meier, M. F., Dyurgerov, M. B., Rick, U. K., O’Neel, S., Pfeffer, W. T., Anderson, R. S., Anderson, S. P., and Glazovsky, A. F.: Glaciers dominate eustatic sea-level rise in the 21 st century, Science, 317, 1064-1067, doi:10.1126/science.1143906, 2007.
Meyers, T. P. and Dale, R. F.: Predicting daily insolation with hourly cloud height and coverage, J. Clim. Appl. Meteorol., 22, 537$545,1983$.

Nakicenovic, N., Alcamo, J., Davis, G., de Vries, B., Fenhann, J., Gaffin, S., Gregory, K., Grübler, A., Jung, T. Y., Kram, T., La Rovere, E. L., Michaelis, L., Mori, S., Morita, T., Pepper, W., Pitcher, H., Price, L., Raihi, K., Roehrl, A., Rogner, H., Sankovski, A., Schlesinger, M., Shukla, P., Smith, S., Swart, R., van Rooijen, S., Victor, N., and Dadi, Z.: IPCC Special Report on Emissions Scenarios, Cambridge University Press, Cambridge, UK and New York, NY, USA, 2000.

Nesje, A. and Dahl, S. O.: Holocene glacier variations of Blåisen, Hardangerjøkulen, central southern Norway, Quaternary Res., 35, 25-40, 1991.

Nesje, A., Dahl, S. O., Løvlie, R., and Sulebak, J. R.: Holocene glacier activity at the southwestern part of Hardangerjøkulen, central-southern Norway: evidence from lacustrine sediments, The Holocene, 4, 377-382, 1994.

Nesje, A., Bakke, J., Dahl, S. O., Lie, Ø., and Matthews, J. A.: Norwegian mountain glaciers in the past, present and future, Global Planet. Change, 60, 10-27, 2008.

Oerlemans, J.: A flowline model for Nigardsbreen, Norway: projection of future glacier length based on dynamic calibration with the historic record, Ann. Glaciol., 24, 382-389, 1997.

Oerlemans, J.: Glaciers and Climate Change, Balkema, Lisse, 2001

Oerlemans, J. and Grisogono, B.: Glacier winds and parameterisation of the related surface heat fluxes, Tellus A, 54, 440-452, 2002.

Oerlemans, J. and Knap, W. H.: A 1 year record of global radiation and albedo in the ablation zone of Morteratschgletscher, Switzerland, J. Glaciol., 44, 231-238, 1998.

Oerlemans, J. and Reichert, B. K.: Relating glacier mass balance to meteorological data by using a seasonal sensitivity characteristic, J. Glaciol., 46, 1-6, 2000.

Oerlemans, J., Giesen, R. H., and Van den Broeke, M. R.: Retreating alpine glaciers: increased melt rates due to accumulation of dust (Vadret da Morteratsch, Switzerland), J. Glaciol., 55, 729_ 736, 2009.

Østen, K.: Radio-ekko unders $\varnothing$ kelser på Midtdalsbreen, Sør-Norge, Master's thesis, Geographical Institute, University of Oslo, 1998.

Østrem, G., Dale Selvig, K., and Tandberg, K.: Atlas over breer i Sør-Norge (Atlas of glaciers in south Norway), Meddelelser fra Hydrologisk Avdeling 61, Norwegian Water Resources and Energy Directorate, Oslo, 248 pp., 1988.

Pytte, R. and Liest $\varnothing 1$, O.: Glasio-hydrologiske unders $\varnothing$ kelser i Norge 1965 (Glacio-hydrological investigations in Norway 1965), NVE Annual Report, Norwegian Water Resources and Energy Directorate, Oslo, 64 pp., 1966.

Räisänen, J., Hansson, U., Ullerstig, A., Döscher, R., Graham, L. P., Jones, C., Meier, H. E. M., Samuelsson, P., and Willén, U.: European climate in the late twenty-first century: regional simulations with two driving global models and two forcing scenarios, Clim. Dynam., 22, 13-31, 2004.

Rasmussen, L. A. and Conway, H.: Influence of upper-air conditions on glaciers in Scandinavia, Ann. Glaciol., 42, 402-408, 2005 
Roeckner, E., Bengtsson, L., Feichter, J., Lelieveld, J., and Rodhe, H.: Transient climate change simulations with a coupled atmosphere-ocean GCM including the tropospheric sulfur cycle, J. Climate, 12, 3004-3032, 1999.
Van den Berg, J., Van de Wal, R. S. W., and Oerlemans, J.: A mass balance model for the Eurasian Ice Sheet for the last 120,000 years, Global Planet. Change, 61, 194-208, 2008. 